\title{
Resource Characterization and Quantification of Natural Gas-Hydrate and Associated Free-Gas Accumulations in the Prudhoe Bay - Kuparuk River Area on the North Slope of Alaska \\ December, 2002 Quarterly and Year-End Technical Report First Quarterly Report: October, 2002 - December, 2002 Cooperative Agreement Award Number DE-FC-01NT41332
}

\author{
Submitted to the \\ United States Department of Energy \\ National Energy Technology Laboratory \\ ADD Document Control \\ by \\ BP Exploration (Alaska), Inc. \\ Robert Hunter (Principal Investigator) \\ P.O. Box 196612 \\ Anchorage, Alaska 99519-6612 \\ Email: hunterrb@bp.com \\ Tel: (907)-696-2124, (907)-564-5733 \\ with \\ University of Alaska Fairbanks \\ Shirish Patil (Principal Investigator) \\ 425 Duckering Building \\ P.O. Box 755880 \\ Fairbanks, Alaska 99775-5880 \\ and \\ University of Arizona, Tucson \\ Robert Casavant (Principal Investigator) \\ Dept. Mining and Geological Engineering \\ Rm. 245, Mines and Metallurgy Bldg. \#12 \\ 1235 E. North Campus Dr., POB 210012 \\ Tucson, AZ 85721-0012 \\ in collaboration with \\ United States Geological Survey \\ Tim Collett (Principal Investigator) \\ Denver Federal Center \\ Box 25046, MS939 \\ Denver, CO 80225
}

January 21, 2003 (Original submission)

June 2, 2003 (Re-submission for corrected format) 


\title{
DISCLAIMER
}

This report was prepared as an account of work sponsored by an agency of the United States Government. Neither the United States Government nor any agency thereof, nor any of their employees, makes any warranty, express or implied, or assumes any legal liability or responsibility for the accuracy, completeness, or usefulness of any information, apparatus, product, or process disclosed, or represents that its use would not infringe privately owned rights. Reference herein to any specific commercial product, process, or service by trade name, trademark, manufacturer, or otherwise does not necessarily constitute or imply its endorsement, recommendation, or favoring by the United States Government or any agency thereof. The views and opinions of authors expressed herein do not necessarily state or reflect those of the United States Government or any agency thereof.

\begin{abstract}
Interim results are presented from the project designed to characterize, quantify, and determine the commercial feasibility of Alaska North Slope (ANS) gas-hydrate and associated free-gas resources in the Prudhoe Bay Unit (PBU), Kuparuk River Unit (KRU), and Milne Point Unit (MPU) areas. This collaborative research will provide practical input to reservoir and economic models, determine the technical feasibility of gas hydrate production, and influence future exploration and field extension of this potential ANS resource.
\end{abstract}

The large magnitude of unconventional in-place gas (40 - 100 TCF) and conventional ANS gas commercialization evaluation creates industry-DOE alignment to assess this potential resource. This region uniquely combines known gas hydrate presence and existing production infrastructure. Many technical, economical, environmental, and safety issues require resolution before enabling gas hydrate commercial production.

Gas hydrate energy resource potential has been studied for nearly three decades. However, this knowledge has not been applied to practical ANS gas hydrate resource development. ANS gas hydrate and associated free gas reservoirs are being studied $\mathrm{o}$ determine reservoir extent, stratigraphy, structure, continuity, quality, variability, and geophysical and petrophysical property distribution. Phase 1 will characterize reservoirs, lead to recoverable reserve and commercial potential estimates, and define procedures for gas hydrate drilling, data acquisition, completion, and production. Phases 2 and 3 will integrate well, core, log, and long-term production test data from additional wells, if justified by results from prior phases. The project could lead to future ANS gas hydrate pilot development.

This project will help solve technical and economic issues to enable government and industry to make informed decisions regarding future commercialization of unconventional gas-hydrate resources. 


\section{TABLE OF CONTENTS}

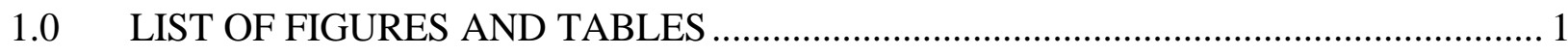

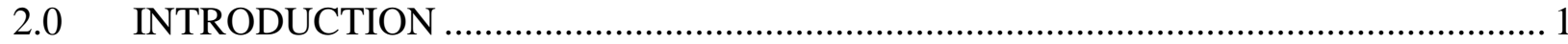

2.1 Alaska Gas Hydrate Historical Events Summary ........................................................ 2

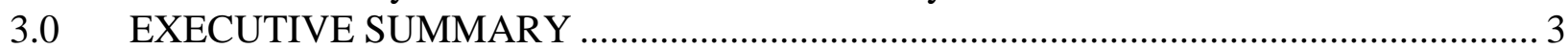

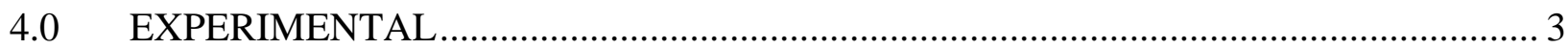

4.1 TASK 6.0, Reservoir and Fluids Characterization ...................................................... 3

4.1.1 Subtask 6.1: Reservoir and Fluid Characterization and Visualization .................... 3

4.1.2 Subtask 6.2: Seismic Attributes and Calibration ................................................. 4

4.1.3 Subtask 6.3: Petrophysics and Artificial Neural Net ........................................... 4

4.2 TASK 7.0: Laboratory Studies for Drilling, Completion, and Production Support ....... 4

4.2.1 Subtask 7.1: Characterize Gas Hydrate Equilibrium ............................................. 4

4.2.2 Subtask 7.2: Measure Gas-Water Relative Permeabilities ................................... 4

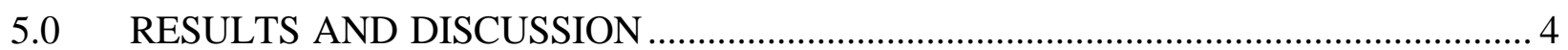

5.1 TASK 1.0: Research Management Plan - BP and Project Team .................................... 4

5.2 TASK 2.0: Provide Technical Data and Expertise - BP, USGS ................................... 5

5.3 TASK 3.0: Wells of Opportunity, Data Acquisition - BP ............................................... 7

5.4 TASK 4.0: Research Collaboration Link - BP, USGS, Project team............................. 8

5.5 TASK 5.0: Logging and Seismic Technology Advances - USGS, BP ........................ 10

5.6 TASK 6.0: Reservoir and Fluids Characterization - UA ……….............................. 11

5.6.1 Subtask 6.1: Reservoir and Fluid Characterization and Visualization - UA........ 11

5.6.2 Subtask 6.2: Seismic Attributes and Calibration - UA............................................. 11

5.6.3 Subtask 6.3: Petrophysics and Artificial Neural Net - UA ................................ 12

5.7 TASK 7.0: Lab Studies for Drilling, Completion, and Production Support - UAF .... 12

5.7.1 Subtask 7.1: Characterize Gas Hydrate Equilibrium - UAF ………………......... 12

5.7.2 Subtask 7.2: Measure Gas-Water Relative Permeabilities - UAF ........................ 12

5.8 TASK 8.0: Evaluate Drilling Fluids - UAF ………….......................................... 12

5.9 TASK 9.0: Design Cement Program - UAF …………………………………..... 12

5.10 TASK 10.0: Study Coring Techno logy - UAF …………………............................ 12

5.11 TASK 11.0: Reservoir Modeling - UAF, BP (+LBNL) ……………………….... 12

5.12 TASK 12.0: Select Drilling Location and Candidate - BP, UA.................................. 13

5.13 TASK 13.0: Project Commerciality and Progression Assessment - BP, UAF ........... 13

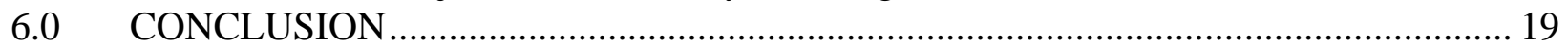

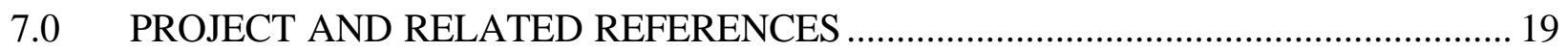

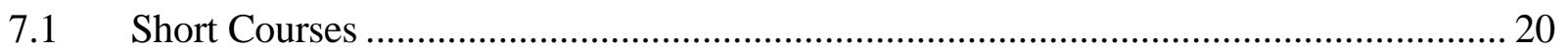

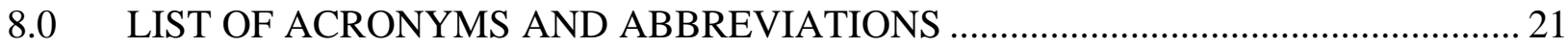




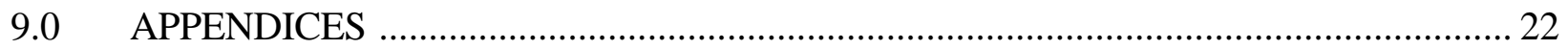

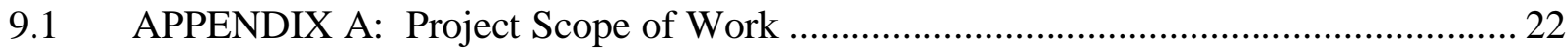

PROJECT OBJECTIVES ……………………………………………………… 22

9.2 APPENDIX B: Project Task Schedules and Milestones ……………………….......... 33

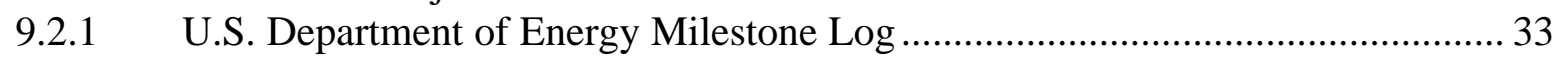

9.2.2 U.S. Department of Energy Milestone Plan............................................................ 35

9.3 APPENDIX C: Project Budgets for BP and Subcontractors (UA and UAF) ................ 36

9.3.1 BP Exploration (Alaska), Inc. Original Project Budget Pages ............................... 36

9.3.1.1 BP Exploration (Alaska), Inc. Original Project Budget Year 1, Phase 1 ............... 36

9.3.1.2 BP Exploration (Alaska), Inc. Original Project Budget Year 2, Phase 1 .............. 37

9.3.1.3 BP Exploration (Alaska), Inc. Original Project Budget Year 3, Phase 2 2.............. 38

9.3.1.4 BP Exploration (Alaska), Inc. Original Project Budget Year 4, Phase 3 ............... 39

9.3.1.5 BP Exploration (Alaska), Inc. Original Project Budget Total Project................... 40

9.3.2 University of Arizona (Tucson) Original Project Budget Pages ............................ 41

9.3.2.1 University of Arizona (Tucson) Original Project Budget Year 1 .......................... 41

9.3.2.2 University of Arizona (Tucson) Original Project Budget Year 2 ......................... 45

9.3.2.3 University of Arizona (Tucson) Original Project Budget Year 3 .......................... 49

9.3.2.4 University of Arizona (Tucson) Original Project Budget Year 4 ......................... 53

9.3.2.5 University of Arizona (Tucson) Original Project Budget, Total Project ............... 56

9.3.3 University of Alaska Fairbanks Original Project Budget Pages ............................. 57

9.3.3.1 University of Alaska Fairbanks Original Project Budget Year 1 ......................... 57

9.3.3.2 University of Alaska Fairbanks Original Project Budget Year 2 ……………...... 58

9.3.3.3 University of Alaska Fairbanks Original Project Budget Year 3 ………..............59

9.3.3.4 University of Alaska Fairbanks Original Project Budget Year 4 ............................60

9.3.3.5 University of Alaska Fairbanks Original Project Budget, Total Project ............... 61

9.3.3.6 University of Alaska Fairbanks Original Project Budget, UAF Match................. 62 


\subsection{LIST OF FIGURES AND TABLES}

Table 1: Alaska Gas Hydrate Historical Events Summary ...................... Page 2

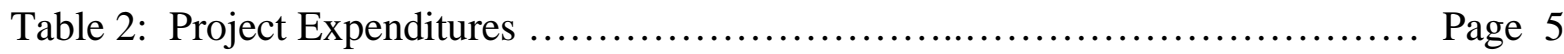

Figure 1: ANS Methane Gas Hydrates Assessment Pre-Phase 1 Commercial Scoping Page 13

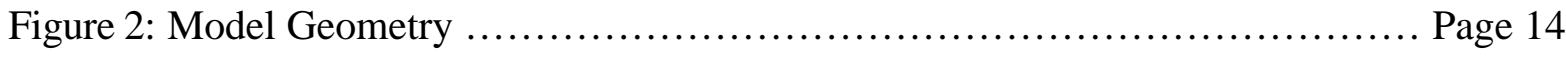

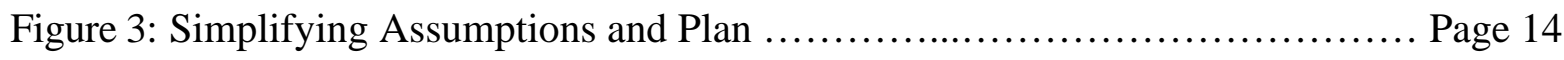

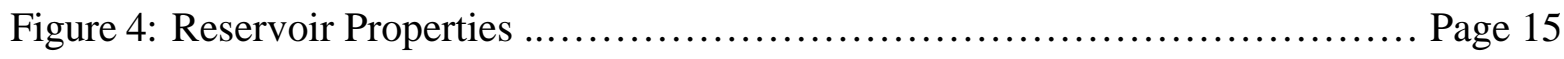

Figure 5: Wells and Surface Facilities ................................... Page 15

Figure 6: ProCast Gas Network Model (time $=12$ years $) \ldots \ldots \ldots \ldots \ldots \ldots \ldots \ldots \ldots$ Page 16

Figure 7: Reservoir Performance from LBNL Model ......................... Page 16

Figure 8: Incorporation of LBNL Model Results $\ldots \ldots \ldots \ldots \ldots \ldots \ldots \ldots \ldots \ldots \ldots \ldots$ Page 17

Figure 9: Impact of Hydrate Dissociation on Rates ........................ Page 17

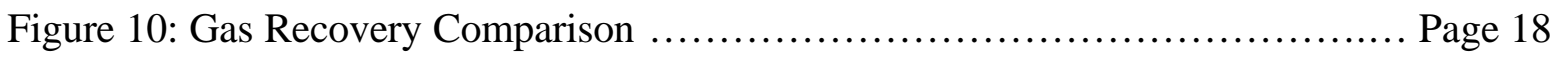

Figure 11: Conclusions ............................................ Page 18

\subsection{INTRODUCTION}

This project unofficially began in September, 2001 after proposal submission on April 23, 2001. Announcement of award occurred on October 19, 2001. The project was officially contracted effective October 21, 2002, but retroactive to September 30, 2001.

Contract negotiations and discussions began in September, 2001. The project scope of work was discussed, modified, and agreed by October 1, 2001. A request for multiple cost/budget clarifications was received from DOE on September 20, 2001 and responded to by BP on September 26, 2001. On October 18, 2001, DOE requested more comprehensive cost clarifications. BP responded to these clarifications in a letter with multiple attachments dated November 5, 2001.

By December, 2001, initial cost sharing issues were agreed. BP and DOE agreed to final confirmation of cost sharing through contribution of in-kind seismic data by January 17, 2002. On February 6, 2002, a potential conflict with using the limited rights (confidential) 
seismic data as cost-share data was discussed and resolved by February 11, 2002, when DOE acknowledged that the seismic data could be used for cost-share and still be maintained as confidential data. The initial project team kickoff meetings were held from February 21-22, 2002 in Tucson. Thomas Mroz, Contracting Officer's Representative, attended these meetings on behalf of NETL/DOE.

Contract administrative delays continued through August, 2002. Unfortunately, BP could not release data to the project until data confidentiality issues were contractually specified. The project team was maintained at minimal operating costs until the final official contract was issued by DOE and executed by BP on October, 21, 2002. Subcontracts between BP and University of Arizona (UA) and University of Alaska Fairbanks (UAF) were executed in October and November, 2002, respectively. Initial release of 3D seismic and well data from BP to project occurred on December 6, 2002.

\subsection{Alaska Gas Hydrate Historical Events Summary}

Table 1 presents an historical events summary to illustrate the timing and significance of government and industry alignment required to accomplish this project.

TABLE 1: Alaska Gas Hydrate Historical Events Summary

\begin{tabular}{|l|l|}
\hline$\underline{\text { TIME }}$ & $\underline{\text { EVENT }}$ \\
\hline 1984-present & Industry supports and discusses ANS gas hydrate research with DOE and USGS \\
\hline $1996,1998-99$ & Industry discusses possibility of joint DOE-USGS-Industry gas hydrate research \\
\hline January, 2001 & DOE-BP-Industry resume discussions of joint gas hydrate research project \\
\hline March, 2001 & BP determines DOE proposal solicitation response aligned with gas strategy \\
\hline April, 2001 & BP submits Alaska gas hydrate and associated free gas proposal to DOE \\
\hline September, 2001 & BP receives verbal notification from DOE of proposal award, \$13MM \\
\hline October, 2001 & DOE formally announces project awards, BP one of 6 awards totaling \$30MM \\
\hline October, 2002 & BP - DOE formally execute project contract for Phase 1, 2-year research project \\
\hline
\end{tabular}




\subsection{EXECUTIVE SUMMARY}

Due to delay of contract execution until October, 2002, this Quarterly report encompasses project work from August 1, 2001, inclusive through December 31, 2002. Contractual specification of data confidentiality allowed BP to release confidential seismic data to the project under confidentiality constraints.

- Coordinated project work and planning meetings with USGS, UA, UAF

- Finalized and executed project contract (DOE) and subcontracts (UA and UAF)

- Submitted project patent waiver application documents

- Coordinated project research with other methane hydrate research programs

- Obtained \$750,000 software for UA through Landmark University Grant Program

- Presented project to industry partners, Exxon-Mobil and Conoco-Phillips

- Released confidential 3D seismic data within MPU to project

- Acquired shallow open-hole log data at MPU E and S pads and PBU L and V pads

- Presented project summary at AAPG-SPE Western Region Meeting in Anchorage

- Planned and designed secure labs for UA hardware, software, and network system

- Successfully loaded 3D seismic data onto UA computing system

- Tested and calibrated UA seismic finite-difference modeling algorithms

- Began preliminary research on neural network mapping and analyses

- Drafted initial BP - JNOC Collaborative Research Agreement

- Provided JNOC gas hydrate program review and well cost estimates

- Planned, designed, and ordered Phase Behavior experimental apparatus for UAF

- Planned experimental apparatus for two-phase (gas, hydrate-water) relative permeability measurements at UAF

- Worked with AETDL and DOE to sponsor separate UAF/PNNL research proposal to study the potential for $\mathrm{CO}_{2}$ as an enhanced recovery mechanism for methane hydrate

- Completed collaborative BP-LBNL pre-Phase 1 scoping reservoir model study

- Study demonstrates first-ever potential gas production commerciality from gas hydrate across broad regional contact with adjacent free gas depressurization

\subsection{EXPERIMENTAL}

During the time period encompassed by this report, primary experimental activities consisted of experimental apparatus planning, design, and setup. Experiment apparatus design plans will be provided in a future report.

\subsection{TASK 6.0, Reservoir and Fluids Characterization}

BP released well data from the PBU, MPU, and KRU region and 3D seismic data within MPU under confidentiality constraints to the project. The University of Arizona (UA) loaded this data onto computing and mapping systems in preparation for interpretation.

\subsubsection{Subtask 6.1: Reservoir and Fluid Characterization and Visualization}

Successfully loaded MPU seismic data from the Milne Point and NW Eileen 3D surveys. 


\subsubsection{Subtask 6.2: Seismic Attributes and Calibration}

Tested and calibrated seismic finite-difference modeling algorithms for gas hydrate research.

\subsubsection{Subtask 6.3: Petrophysics and Artificial Neural Net}

Began preliminary research on neural network mapping and analyses.

\subsection{TASK 7.0: Laboratory Studies for Drilling, Completion, and Production Support}

The University of Alaska Fairbanks (UAF) designed experiments and apparatus for gas hydrate equilibrium and relative permeability studies.

\subsubsection{Subtask 7.1: Characterize Gas Hydrate Equilibrium}

Completed final experimental apparatus design and ordered equipment for Gas Hydrate Phase Equilibrium studies (from DBRobinson Oil Phase, Canada).

\subsubsection{Subtask 7.2: Measure Gas-Water Relative Permeabilities}

Completed experimental apparatus design and ordered equipment parts and accessories for gas hydrate relative permeability studies.

\subsection{RESULTS AND DISCUSSION}

Project technical accomplishments from August, 2001 through December, 2002 are presented in chronological order by associated project task.

\subsection{TASK 1.0: Research Management Plan - BP and Project Team}

The attached Project Scope of Work in Appendix A defines overall project objectives and summarizes the technical objectives and approach. Appendix B contains task schedules and milestones forms. Table 2 shows expenditures by budget category and associated task. Appendix $\mathrm{C}$ contains original detailed project budgets for $\mathrm{BP}$ and subcontractors.

- 9/01 - 11/01: Project technical and cost clarifications negotiations, BP - DOE

- 10/1/01: Project scope-of-work agreement, BP - DOE

- 10/01: Project planning meetings, Anchorage: BP, USGS, (+UA teleconference)

- USGS meetings with DNR and BLM

- 10/01: Initiate intellectual property and subcontract discussions with UA and UAF

- 11/01: Finalize project budgets and initiate BP project accounting procedures

- 2/02: Project team Kickoff/Planning meetings, Tucson: BP, UA, UAF, DOE

- Establish project steering committee

- Clarify industry and academic partner roles, responsibilities, synergy

- Discuss draft contracts, previous hydrate work, lab visits

- Technical focus sessions on proposed geoscience/engineering activites.

- 5/02: Project team meetings and planning, Anchorage: BP, UA, UAF, USGS

- Contract timing discussions and concerns

- Technical focus sessions and project planning

- GeoProbe software demonstration in HIVE 
- 6/02: Release BP subcontract drafts with generic DOE flow-down provisions for UA and UAF review; provide letters of support and commitment to UA and UAF

- 6/02: DOE initiates release of pre-contract funds through US Treasury Department Automated Standard Application for Payments (ASAP) system

○ 7/02: Setup BP Authority for Expenditure project accounting procedures

$\circ$ 7/02: Finalize BP ASAP enrollment and authorize UA operations funding

- UA unable to process operations funds without subcontract

- BP unable to release data or subcontract without DOE contract

- 7/02: BP Prepares project patent waiver application documents

- 10/02: Submit final patent waiver application documents to DOE Chicago

- 8/02 - 10/02: Complete BP - DOE contract revisions and execute contract

- 8/02: Receive initial DOE contract; negotiate provisions modifications

- 10/21/02: BP formally executes DOE contract

- 9/02: Prepare research management plans summary for UAF Tasks: BP, UAF

- 9/02: Provide BP letters of intent to subcontract to UA and UAF

- 9/02: Complete BP-UAF Subcontract negotiations

- 10/02: Complete negotiations and execute BP-UA Subcontract, copies to DOE

- 10/25/02: Initial project invoice reimbursement from ASAP

- 11/02: Execute BP-UAF Subcontract, copies to DOE

\subsection{TASK 2.0: Provide Technical Data and Expertise - BP, USGS}

- 9/01 - 10/01: Prepare draft data confidentiality agreements for MPU, PBU, KRU

- 10/01: Send draft confidentiality agreement to Phillips KRU for review

- 10/01: Review shallow seismic data quality; finalize possible 3D survey selection

- 10/01 - 12/02: BP Project briefings: MPU, PBU, KRU, BP Canada (ongoing)

- 11/01: USGS collates gas hydrate distribution maps and supporting data developed in USGS/USDOE Alaska gas hydrate research during the 1980's. Forward compiled data to BP to integrate into to project data management system.

- 11/01: USGS updates Eileen-trend gas hydrate reservoir model and forwards modifications to LBNL and BP.

- 12/01: USGS prepares report supporting USDOE gas hydrate research objectives on the North Slope of Alaska, which identify and map the distribution of potential gas hydrate accumulations along western and southern margins of the Kuparuk River Unit (KRU), North Slope, Alaska (ANS). This report focuses on the analysis of downhole log data from 16 wells drilled along western and southern margins of the KRU.

- 12/01: BP MPU agrees to shallow data release once data confidentiality issues contractually specified

- 12/01: BP sponsors and initiates negotiations with Landmark Graphics Corporation to obtain $\$ 750,000$ worth of geoscience software for UA through Landmark University Grant Program Addendum

○ 5/02: UA completes negotiations with Landmark Graphics Corporation to provide critical geoscience software to UA

- 12/02: Collate data and software to renew UA Landmark Grant software 
Table 2: Project Expenditures

\begin{tabular}{|c|c|c|c|c|c|c|c|c|}
\hline \multicolumn{9}{|c|}{ BUDGET PERIOD 1 (2 year) COSTS SUMMARY } \\
\hline BP AFE \# & Cost Category & $\%$ Obligated & NET COSTS & Budget Period 1 & GROSS COSTS & SPENT COSTS & BALANCE FUNDS & REMAINING \\
\hline GS2420H01 & U. Arizona, Labor & $90.168 \%$ & $\$ 779,125$ & $\$ 864,077$ & $\$ 779,125$ & $\$ 56,351$ & $\$ 722,773$ & $93 \%$ \\
\hline GS2420H02 & U. Arizona, Travel & $90.168 \%$ & $\$ 43,473$ & $\$ 48,213$ & $\$ 43,473$ & $\$ 1,802$ & $\$ 41,671$ & $96 \%$ \\
\hline GS2420H03 & U. Arizona, Third Party & $90.168 \%$ & $\$ 55,735$ & $\$ 61,812$ & $\$ 55,735$ & $\$ 7,853$ & $\$ 47,882$ & $86 \%$ \\
\hline GS2420H04 & U. Arizona, Operations & $90.168 \%$ & $\$ 155,311$ & $\$ 172,245$ & $\$ 155,311$ & $\$ 22,798$ & $\$ 132,513$ & $85 \%$ \\
\hline GS2420H05 & U. AK Fairbanks, Labor & $90.168 \%$ & $\$ 414,007$ & $\$ 459,148$ & $\$ 414,007$ & $\$ C$ & $\$ 414,007$ & $100 \%$ \\
\hline GS2420H06 & U. AK Fairbanks, Travel & $90.168 \%$ & $\$ 26,528$ & $\$ 29,420$ & $\$ 26,528$ & $\$ C$ & $\$ 26,528$ & $100 \%$ \\
\hline GS2420H07 & U. AK Fairbanks, Third Party & $90.168 \%$ & $\$ 39,791$ & $\$ 44,130$ & $\$ 39,791$ & $\$ C$ & $\$ 39,791$ & $100 \%$ \\
\hline GS2420H08 & U. AK Fairbanks, Operations & $90.168 \%$ & $\$ 89,029$ & $\$ 98,736$ & $\$ 89,029$ & $\$ C$ & $\$ 89,029$ & $100 \%$ \\
\hline GS2420H09 & BPXA, Third Party Labor* & $90.168 \%$ & $\$ 236,284$ & $\$ 262,047$ & $\$ 236,284$ & $\$ 76,07 \varepsilon$ & $\$ 160,205$ & $68 \%$ \\
\hline GS2420H10 & BPXA, Travel & $90.168 \%$ & $\$ 25,247$ & $\$ 28,000$ & $\$ 25,247$ & $\$ 1,550$ & $\$ 23,698$ & $94 \%$ \\
\hline \multirow[t]{2}{*}{ GS2420H11 } & BPXA, Operations & $90.168 \%$ & $\$ 9,017$ & $\$ 10,000$ & $\$ 9,017$ & $\$ 243$ & $\$ 8,774$ & $97 \%$ \\
\hline & TOTAL & $90.168 \%$ & $\$ 1,873,546$ & $\$ 2,077,828$ & $\$ 1,873,546$ & $\$ 166,675$ & $\$ 1,706,87$ & $91 \%$ \\
\hline
\end{tabular}

* Only include DOE funds (If include BP funds, add

$\$ 84,063)$

\begin{tabular}{|c|c|c|}
\hline BP AFE \# & Cost Category & $\begin{array}{l}\text { Project } \\
\text { Tasks }^{* *}\end{array}$ \\
\hline GS2420H01 & U. Arizona, Labor & $\begin{array}{l}\text { Task 6.0, } \\
6.1,6.2,6.3\end{array}$ \\
\hline GS2420H02 & U. Arizona, Travel & $\begin{array}{l}\text { Task 6.0, } \\
6.1,6.2,6.3\end{array}$ \\
\hline GS2420H03 & U. Arizona, Third Party & $\begin{array}{l}\text { Task 6.0, } \\
6.1,6.2,6.3\end{array}$ \\
\hline GS2420H04 & U. Arizona, Operations & $\begin{array}{l}\text { Task 6.0, } \\
6.1,6.2,6.3\end{array}$ \\
\hline GS2420H05 & U. AK Fairbanks, Labor & $\begin{array}{l}\text { Tasks } 7,8 \\
9,10,11,13\end{array}$ \\
\hline GS2420H06 & U. AK Fairbanks, Travel & $\begin{array}{l}\text { Tasks } 7,8 \\
9,10,11,13\end{array}$ \\
\hline GS2420H07 & U. AK Fairbanks, Third Party & $\begin{array}{l}\text { Tasks } 7,8 \\
9,10,11,13\end{array}$ \\
\hline GS2420H08 & U. AK Fairbanks, Operations & $\begin{array}{l}\text { Tasks } 7,8 \\
9,10,11,13\end{array}$ \\
\hline GS2420H09 & BPXA, Third Party Labor & $\begin{array}{l}\text { Tasks } 1,2 \text {, } \\
3,4,11,12 \text {, } \\
13\end{array}$ \\
\hline GS2420H10 & BPXA, Travel & $\begin{array}{l}\text { Tasks 1, 2, } \\
3,4,11,12 \text {, } \\
13\end{array}$ \\
\hline GS2420H11 & BPXA, Operations & $\begin{array}{l}\text { Tasks 1, 2, } \\
3,4,11,12 \text {, } \\
13\end{array}$ \\
\hline
\end{tabular}

** Project Task 5.0 performed by USGS under separate funding 
- 1/02: BP response to Senator Murkowski staff inquiry: provide project briefing

- 1/02: BP reviews and locates well log data for data release agreement exhibits

- 1/02: BP identifies and finalizes limited rights data to DOE for project contract

○ 2/02: final modifications to limited rights data at DOE request

- 2/02: BP evaluates selected 3D seismic surveys

- Determine shallow data truncation limits and confirm data quality

- 2/02: BP presents project to Exxon, discuss draft data sharing ballot for PBU

- 3/02: BP presents project to Phillips, discuss draft data sharing ballot for KRU

- 5/02: BP reviews available velocity and check-shot data for ballot agreements

- 5/02: BP attends Landmark City Forum technical presentations

- 5/02: BP presents project to Phillips, discuss draft data sharing ballot for PBU

- 6/02: BP initiates well data compilation for Eileen trend shallow log data

- 6/02: USGS prepares nine-section report containing all USGS-internal gas hydrate assessment notes and a comprehensive listing of all assessed wells known to contain gas hydrates on the North Slope. Each well notation includes specific information about the potential occurrence and depth of gas hydrates and hydrate associated freegas. The compilation also lists recently drilled wells, which require assessment for the potential occurrence of gas hydrates.

- 6/02: USGS prepares a CD-ROM based technical report containing scanned versions of nine well log correlation sections (total of 120 wells) through the PBU-KRU area (also includes several composite sections and a scanned version of base map). These well log correlations sections were originally developed during the 1980's USGS/USDOE northern Alaska gas hydrate research

- 8/02: Donate 6 BP SGI Octane and 2 Sun Ultra 30 workstations to UA

- 10/02: BP management, PBU, and MPU meetings confirm high-level support

- 11/02: Initiate arrangements to provide Landmark support to UA

- 12/02: Complete Milne Point Unit (MPU) Agreement for Release of Seismic and Well Data with BP-UA-USGS to release confidential MPU data to project

$\circ$ Release shallow Milne Point and NW Eileen 3D surveys within MPU

\subsection{TASK 3.0: Wells of Opportunity, Data Acquisition - BP}

- (4/01: BP funds and acquires first shallow log data (logging-while drilling) over suspected gas hydrate-bearing intervals at MPU E-pad, MPE-26)

○ 12/02: MPE-26 log data released to project with MPU Data Agreement

- 12/01 - 1/02: Collaborate with DOE to co-fund and acquire first shallow wireline log data over suspected gas hydrate-bearing intervals at new Milne Point Unit (MPU) Spad, at MPS-15i; excellent logging results, included dipole sonic.

- 4/02: Release MPS-15i data to DOE and USGS

- 12/02: Release MPS-15i data to project with MPU Data Agreement

- 1/02: BP collaborates with USGS to provide mudlogging samples and gas compositional analyses for MPU S-pad S-15i

- 1/02: Collaborate with Prudhoe Bay Unit (PBU) industry partners to co-fund and acquire first shallow wireline log data over suspected gas hydrate-bearing intervals at new PBU L-pad, at L-106; excellent logging results with dipole sonic reveal thickest 
gas hydrate section ever encountered on ANS, over 200 feet in 2 adjacent Sagavanirktok zones. Data not publicly released pending PBU ballot.

- 1/02 - 3/02: BP plans and acquires high-resolution 3D VSP at MPU to assist S-pad shallow viscous oil development; some fold coverage of gas hydrate intervals

○ Data not evaluated within gas hydrate interval

- Consider DOE funding for Paulsson Geophysics data processing addition

- Data not publicly released

- 6/02 - 12/02: Working to acquire annular gas samples at PBU W- and Z- pads within Eileen trend gas hydrate accumulation (ongoing)

- 6/02: Provide well-of-opportunity cost estimates for JNOC

- 7/02: Data acquisition discussions with BP PBU satellite development teams

- 10/02: Collaborate with PBU industry partners to co-fund and acquire first shallow wireline log data over suspected gas hydrate-bearing intervals at new PBU V-pad, at $\mathrm{V}-107$; excellent logging results with dipole sonic reveal complex geology and fluids. Data not yet publicly released pending PBU ballot.

- 11/02: Investigate funding options for PBU development well L-112 to acquire shallow sonic data during industry-funded shallow data acquisition program

○ Industry-partner approval process required; will include in PBU ballot

- Budgeted account through DOE and/or JNOC would better enable process

- 12/02: Complete Milne Point Unit (MPU) Agreement for Release of Seismic and Well Data with BP-UA-USGS to release confidential MPU data to project

\subsection{TASK 4.0: Research Collaboration Link - BP, USGS, Project team}

- (8/00: USGS (Collett) participates in the Gulf of Mexico Hydrates R\&D Planning Workshop sponsored by the U.S. Department of Energy and Chevron Petroleum Technology Company. Collett also contributes a technical briefing regarding the integrated analyses of in-situ gas hydrate accumulations with core, downhole-logging, and seismic data)

- (5/01: Exchange ideas/proposals with Chevron JIP Gas Hydrate Project Manager)

- 10/01: USGS participates in project informational exchange meetings with representatives from Chevron's DOE-supported JIP Gulf of Mexico research

- 11/01: BP initiates formal contact with JNOC through USGS introductions

- 11/01-2/02: BP plans, coordinates, and develops synergistic proposal resulting in successfully funded NETL/AETDL project with UAF and PNNL to study CO2 as a mechanism to enhance $\mathrm{CH} 4$ recovery from Methane Hydrate

- 11/01: USGS participates in project planning meetings and conducts technical briefings for representatives from Anadarko Petroleum.

- 12/01: BP presents project at BP Innovation and Creativity Conference

- 1/02: BP provides support letters to UAF for other AETDL project proposals

- 1/02-3/02: USGS participates in the Mackenzie Delta Mallik research project.

- 3/02: BP presents project at Alaska Oil and Gas Conservation Commission, with Alaska Department of Natural Resources and Minerals Management Service

- 3/02: BP meetings to discuss participation in Chevron Gulf of Mexico JIP

- 3/02: BP presents project at Houston AAPG Gas Hydrate Committee meeting 
- 3/02: BP and USGS prepare and present project talks at US Department of Energy Interagency Coordination Meeting in Washington, D.C.

- 4/02: UAF plans and coordinates "Future of Fossil Energy in Alaska- Road Mapping" workshop, jointly sponsored by U.S. Department of Energy, and University of Alaska Fairbanks with a section on Gas Hydrates and R\&D issuesAlaska Natural Gas. BP presents project, which was well received at conference.

- 4/02: BP hosts and USGS participates in project planning meetings with 2 Japan National Oil Corporation (JNOC) representatives to discuss potential cooperative research opportunities between the 2 methane hydrate research programs

- 6/02: BP GOM decides to not directly participate in GOM gas hydrate JIP

- 5/02: USGS contributes to a series of project planning and technical meetings with members of ODP Leg 204 (Hydrate Ridge) scientific party (7/02-9/02).

- 5/02: USGS prepares and presents talk at Gulf of Mexico JIP Workshop (Titled: Gas Hydrate Drilling and Coring Issues) in Houston, Texas.

- 5/02: USGS and UAF prepare and teach "Natural Gas Hydrates" short course (Collett and Patil) for more than 40 students at the AAPG-SPE Western Region Meeting, Anchorage, Alaska. Members of project team attend and provide additional input

- 5/02: BP presents project summary at AAPG-SPE Western Region Meeting, Anchorage, Alaska. The presentation was attended by over 100 scientists

- 5/02: BP, USGS, DGGS, BLM meet to discuss gas hydrate project interaction

- 5/02: North Slope field and processing facilities tour for Dr. Poulton, UA

- 5/02: USGS prepares and presents talk at the Third International Conference on Gas Hydrates (Titled: Detailed Analysis of Gas Hydrate Induced Drilling and Production Hazards) in Yokohama, Japan.

- 6/02: USGS participates in project planning meetings with Anadarko Petroleum Corporation representatives to review their gas hydrate research plans in northern Alaska and discuss potential cooperative research opportunities within their USDOE funded Alaska gas hydrate research projects.

- 6/02: Enroll project into BP Helios award competition under innovation category

- 7/02: Provide detailed well-of-opportunity review and cost estimates for JNOC

- Ongoing JNOC communications regarding project research collaboration

- 7/02: BP considers providing limited 3D seismic data to PNNL for new processing technique (still under consideration)

- 7/02-9/02: USGS participates in ODP Leg 204 Hydrate Ridge research program

- 8/02: BP presents project to Colorado School of Mines industry consortium and participates in consortium research planning meetings

- Attempt to recruit CSM post-doc for UAF research

- 8/02: BP initial contact with ONGC (India) gas hydrate researchers

- 12/02: Continued contact with ONGC through UAF

- Inform ONGC BP currently not planning to form Phase 1 JIP

- 9/02: Submit project abstract for 5/03 AAPG meeting in Salt Lake City

- Plan to present interim project results in poster format 
- 9/02: USGS participates in project technical meetings with representatives from the Geological Survey of Canada, Japan National Oil Corporation, and project contractors to assess Mallik2002 gas hydrate production testing program results.

- 9/02: Discuss potential research collaboration with ANL for phosphate-based lowtemperature ceramicrete cement compound; may continue discussions

- 10/02: UA's Dr. Poulton presents gas hydrate research project to UA faculty

- 10/02: UA establishes research links with Dr. Robert Downs, Department of Geosciences, UA, who is beginning a separate DOE-funded gas-hydrate research project with Los Alamos National Labs. Dr. Downs will focus on laboratory measurements of the physical properties of clathrates, and is interested in providing appropriate lab measurements for use in our project seismic and well-log modeling efforts.

- 10/02: USGS prepares and presents talk at the Second Workshop of International Committee on Gas Hydrates (Titled: Well Log Evaluation of Marine and Permafrost Associated Gas Hydrate Accumulations) in Washington, DC.

- 10/02: BP evaluates, adds input, and provides letter of support to UAF-lead CO2 Sequestration proposal to DOE/NETL

- 10/02: BP provides letter of support for University of Kansas proposal to DOE/NETL for Eileen trend gas hydrate area high-resolution 2D seismic survey

- 11/02: BP and USGS participate in project research collaborations planning meetings with 7 Japan National Oil Corporation (JNOC) representatives to discuss potential cooperative research opportunities between the 2 methane hydrate research projects. Four JNOC representatives and USGS attend BP-led tour of Alaska North Slope MPU and PBU surface and production facilities.

- 11/02 - 1/03: Prepare draft BP - JNOC research collaborations plans associated with, but contractually separate from BP - DOE project (ongoing, expect contract in 1Q03)

- 11/02: USGS participates in project technical meetings with representatives from the Geological Survey of Canada, Japan National Oil Corporation, and project contractors to assess Mallik2002 gas hydrate production testing program results.

- 11/02: USGS prepares and presents briefing to USDOE Methane Hydrate Advisory Committee Meeting (Titled: A Review of Arctic Gas Hydrate Studies) in Washington, DC.

- 11/02: USGS participates in USGS Woods Hole project review and planning meetings with representatives from the USDOE, USNOAA, USNSF, and Chevron Petroleum. These meetings were designed to plan USGS gas hydrate research program for the coming decade. BP provides input for presentations.

- 12/02 - 1/03: Prepare agreement between BP Alaska and BP Canada sites for Mallik data sharing

- 1/03: BP Canada and BP Alaska to attend Mallik meetings

\subsection{TASK 5.0: Logging and Seismic Technology Advances - USGS, BP}

- 11/01: USGS prepares preliminary report regarding processing and analysis of openhole log data from the Tarn-trend gas hydrate accumulation. 
- 11/01: USGS participates in project planning and technical meetings with representatives from Schlumberger-Doll regarding acquisition and analysis of downhole log data from Arctic gas hydrate research wells.

- 1/02: USGS participates in project planning and technical meetings with representatives from Schlumberger-Doll regarding acquisition and analysis of downhole log data from Arctic gas hydrate research wells.

\subsection{TASK 6.0: Reservoir and Fluids Characterization - UA}

- 9/01-12/02. Collect literature and review recent gas-hydrate papers in scientific journals and books (on-going).

- 10/01 - 12/02: Train student and faculty on Landmark interpretation software and ProMAX seismic data processing software. (Training is ongoing).

- 12/2001. Visit to BP Alaska by UA graduate student Casey Hagbo to discuss gashydrate project and data and interpretation issues

- 1/02 UA consultant, Ken Mallon, visits UA labs

- Becomes familiar with project objectives and UA capabilities

- Assists UA team in loading and testing various data types in the 3D Petra geologic and PetraSeis geophysical software

- debugs and loads updates of the Petra software; tests and confirms software functions and associated products (e.g. cross-sections, log correlation, curve definitions, composite log displays, mapping functions)

- Recommends lab and workstation configuration

- 7/02: Purchase Sun Blade server system and RAID disk array for project work

- 7/02 - 9/02: Set up project computer analysis laboratory; install Ethernet network

- 8/02: Test 6 BP SGI Octane and 2 Sun Ultra 30 BP-donated workstations, reconfigure as needed, load Landmark Software, and integrate into network.

- 12/02: Upgrade MGE computer analysis laboratory and install Ethernet network

○ Reconfigure MGE network, emplace security patches, update security switch, setup SUN workstations, and load base operating systems

- Add to the existing NIS domain, an initial step prior to establishing a secure data transfer between the MGE and GEOS hydrate labs

- Setup MGE lab and adjoining graduate student study room computer lab

- 12/02: Acquire large format HP color plotter for MGE hydrate lab

\subsubsection{Subtask 6.1: Reservoir and Fluid Characterization and Visualization - UA}

- 12/02: Successfully load BP Milne Point and NW Eileen 3D surveys to GEOS lab

- 12/02: Begin reservoir and fluid characterization studies, Milne Point area

\subsubsection{Subtask 6.2: Seismic Attributes and Calibration - UA}

- 9/01 - 12/02: Test and calibrate seismic finite-difference modeling algorithms for hydrate research. Standard Landmark acoustic-wave finite-difference modeling 
software is not suitable for amplitude analysis, but is useful for geometrical response. Test models to reproduce literature results on gas-hydrate seismic response.

\subsubsection{Subtask 6.3: Petrophysics and Artificial Neural Net - UA}

- 8/01: Acquire Kingdom Suite and Petra software donations

- 12/02: Student begins preliminary research on neural network mapping of selected rock properties using a non-hydrate $\log /$ seismic data

- 12/02: General discussions with Dr. R. Lynn Kirlin, University of Victoria, B.C., on techniques for statistical analysis of hydrate occurrences and pattern recognition techniques that might be used with neural network analyses. Dr. Kirlin is a leading expert in pattern recognition techniques.

\subsection{TASK 7.0: Lab Studies for Drilling, Completion, and Production Support - UAF}

\subsubsection{Subtask 7.1: Characterize Gas Hydrate Equilibrium - UAF}

- 6/02: Complete final design and order equipment for Gas Hydrate Phase Equilibrium studies (from DBRobinson Oil Phase, Canada).

\subsubsection{Subtask 7.2: Measure Gas-Water Relative Permeabilities - UAF}

- 12/02: Order equipment parts and accessories for gas hydrate relative permeability studies; anticipate delivery by end of January 2003 and expect assembly completion by March 2003.

\subsection{TASK 8.0: Evaluate Drilling Fluids - UAF}

No significant progress beyond literature review was made in this task during the report period.

\subsection{TASK 9.0: Design Cement Program - UAF}

No significant progress beyond literature review was made in this task during the report period.

\subsection{TASK 10.0: Study Coring Technology - UAF}

No significant progress beyond literature review was made in this task during the report period.

\subsection{TASK 11.0: Reservoir Modeling - UAF, BP (+LBNL)}

- 12/02 Request core samples, access to LBNL model and preliminary information for scoping economics from BP 


\subsection{TASK 12.0: Select Drilling Location and Candidate - BP, UA}

No significant progress was made in this task during the report period.

\subsection{TASK 13.0: Project Commerciality and Progression Assessment - BP, UAF}

- Completed collaborative BP-LBNL pre-Phase 1 scoping reservoir model study

- 10/02: Complete collaborative BP-LBNL pre-Phase 1 scoping reservoir model and economics study

- Study demonstrates first-ever potential gas production commerciality from gas hydrate across broad regional contact with adjacent free gas depressurization

- Study is a collaborative, approved effort between BP-USGS-LBNL-DOE

- 11/02: Results of study available; results presented to DOE by USGS

The reservoir model study results are presented below in figures 1-11.

\section{ANS Methane Gas Hydrates Assessment Pre-Phase 1 Commercial Scoping}

Development of Simplified Hydrate Production Model

S. Digert \& R. Hunter, BPXA

T. Collett, USGS

G. Moridis, LBNL 


\section{Model Geometry}

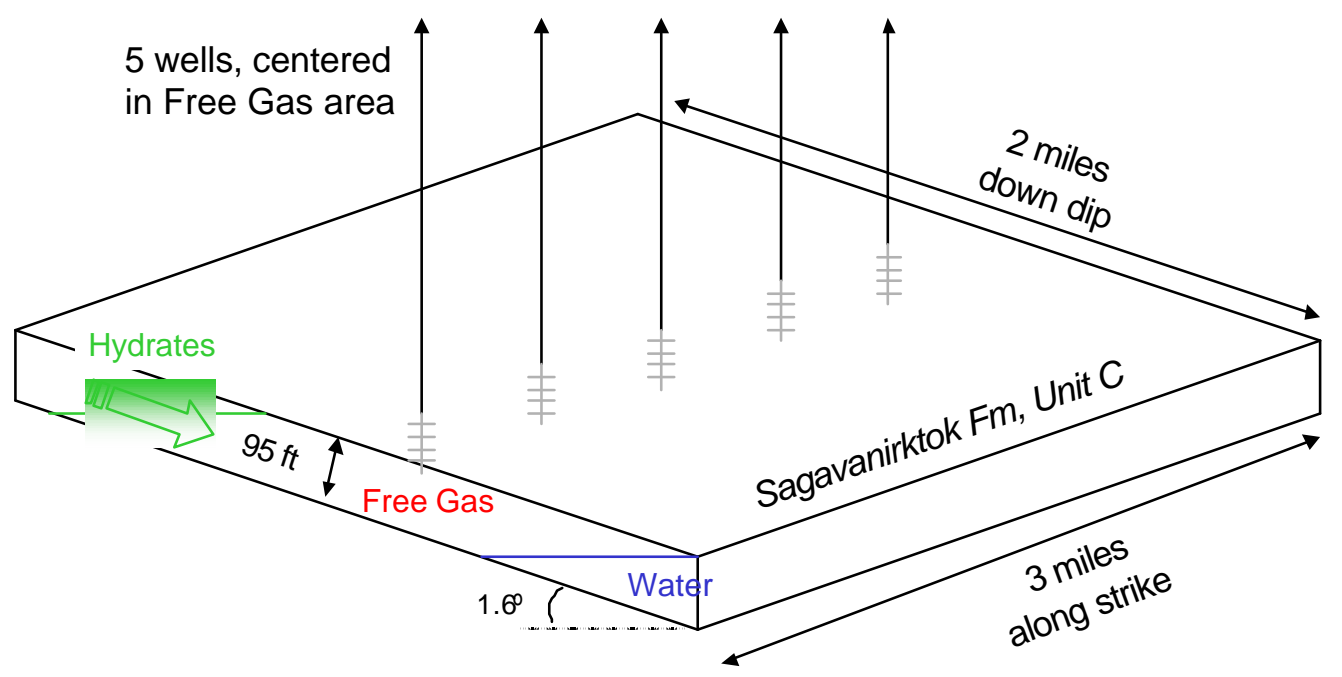

ANS Methane Hydrates Study BP/DOE/USGS

Figure 2

Pre-Phase 1 Scoping

\section{Simplifying Assumptions \& Plan}

- Simple reservoir block as per description by Collett

- Reservoir follows volumetric depletion

- No significant aquifer or formation compressibility drive

- Only additional drive is from dissociation of hydrates

- Wells completed in Free Gas, no boundary effects

- Well spacing and distance from boundaries sufficient to be radial acting at these high perms.

- Base ProCast forecast done without hydrate dissociation

- Forecast for hydrate dissociation at interface to be developed from LBNL's TOUGH2/EOSHYDR2 model, using ProCast base forecast

- Hydrate forecast to be added to ProCast model for combined forecasting and economic scoping. 


\section{$\underline{\text { Reservoir Properties }}$}

- Formation properties:

- Porosity $=36 \%$ avg, in both Hydrate $\&$ Free Gas regions

- Permeability $=800 \mathrm{mD}$ (to gas), in both Hydrate \& Free Gas regions

- Free Gas Composition: 100\% Methane

- Conditions at Hydrate/Free Gas interface (2600' tvd):

- $\mathrm{P}=2600 * 0.435 \mathrm{psi} / \mathrm{ft}=1,131 \mathrm{psia}$

- $\quad T=52 \stackrel{\circ}{\circ} \quad(11.1 \circ \mathrm{C}) \quad$ (Per Sloan stability model at 1131 psia)

- Interface area $=15840 \mathrm{ft} * 95 \mathrm{ft} / \sin (1.60)=53.9 \mathrm{E} 6 \mathrm{ft} 2(5.0 \mathrm{E} 6 \mathrm{~m} 2)$

- Conditions at mid-point of Perfs:

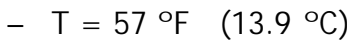

- Pbhf unrestricted, set by Psurf plus total wellbore head \& reservoir IPR

\section{Wells \& Surface Facilities}

- Well Completions

- Assumes 5 type wells, all available at time 0 .

- Assume 450 avg deviation, perfs at 2750' TVD, 3890' MD

- Perfed thru 95' of formation

- Tubing: $4-1 / 2^{\prime \prime}, I D=3.958^{\prime \prime}$

- Skin = 2 (including sand control)

- Tubing Hydraulics Correlation: Cullendar \& Smith

- IPR includes Quadratic turbulence correction near wellbore

- Surface Facilities

- Assumes simple gathering into existing drill site

- Assume on-pad booster compression with 100 psia suction

- Surface piping beyond compressor ignored

- Total rate limited to 150 MMSCF/D max (plateau) 


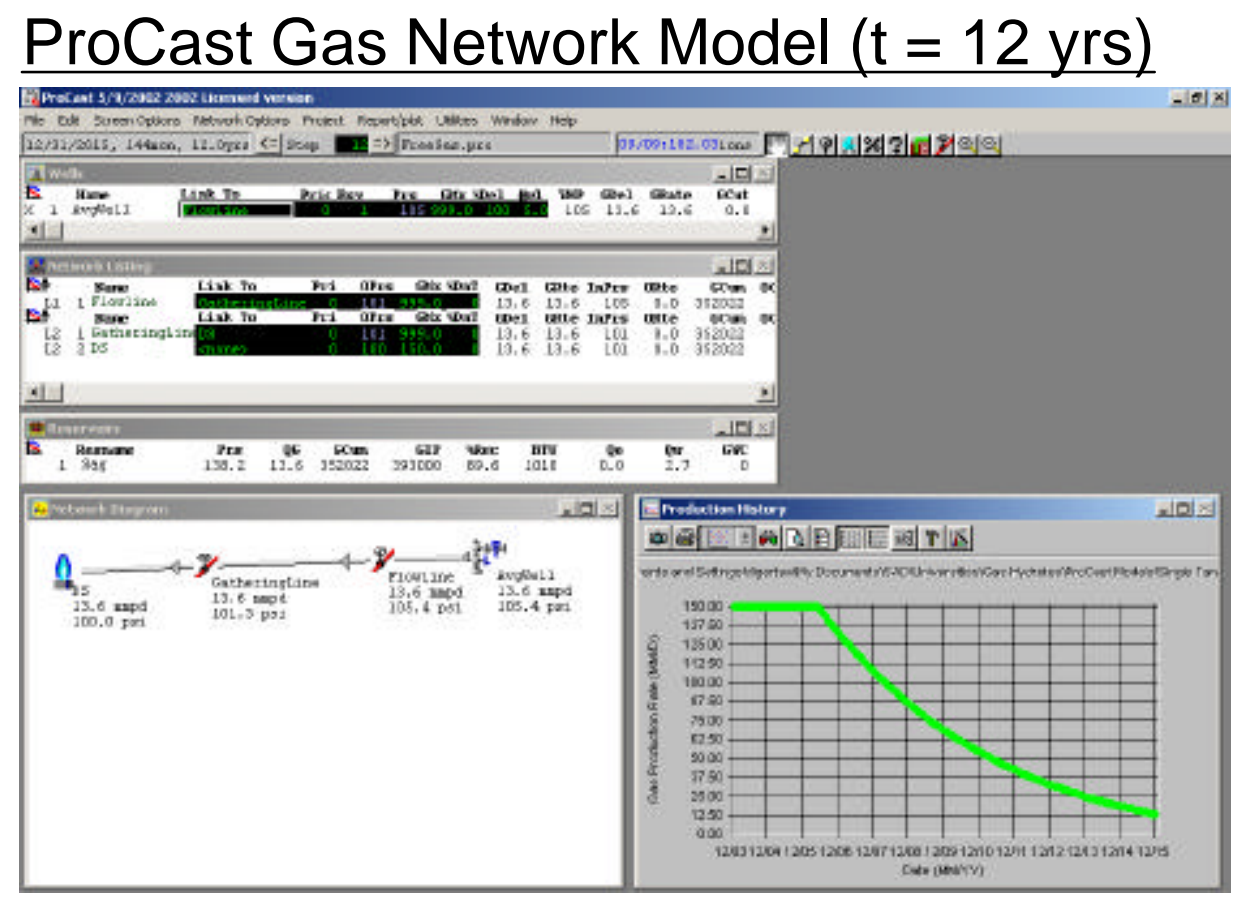

\section{Reservoir Performance from LBNL Model}

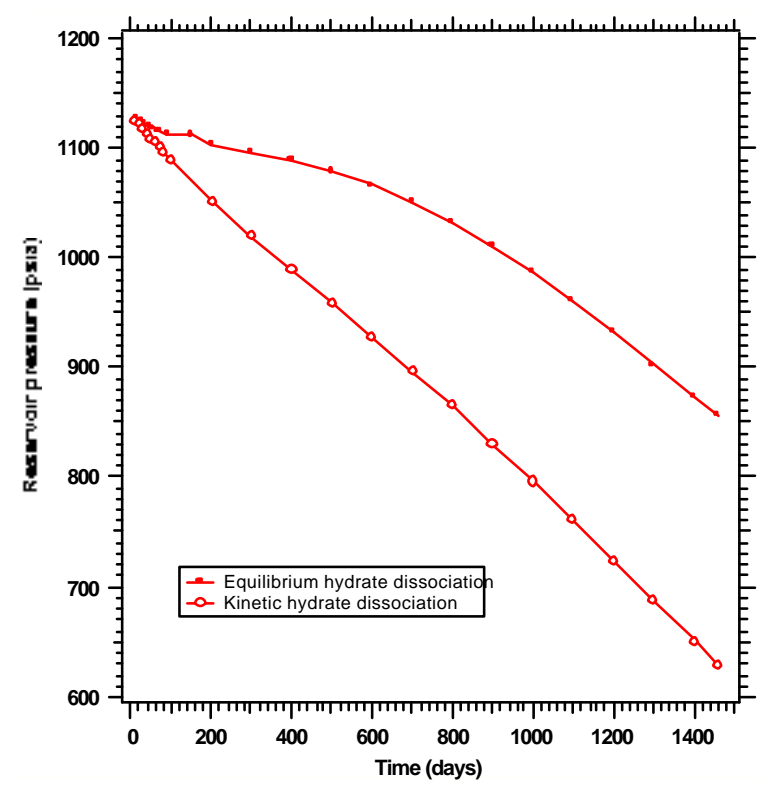




\section{Incorporation of LBNL Model Results}

- Rate performance not proportional to $\Delta \mathrm{P}$; cannot incorporate as infinite-acting source

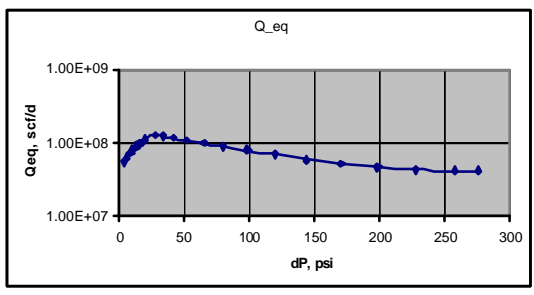

- Hydrate dissociation incorporated as a Q vs t forecast:

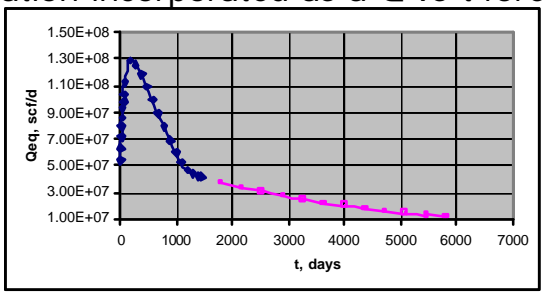

\section{Impact of Hydrate Dissociation on Rates:}

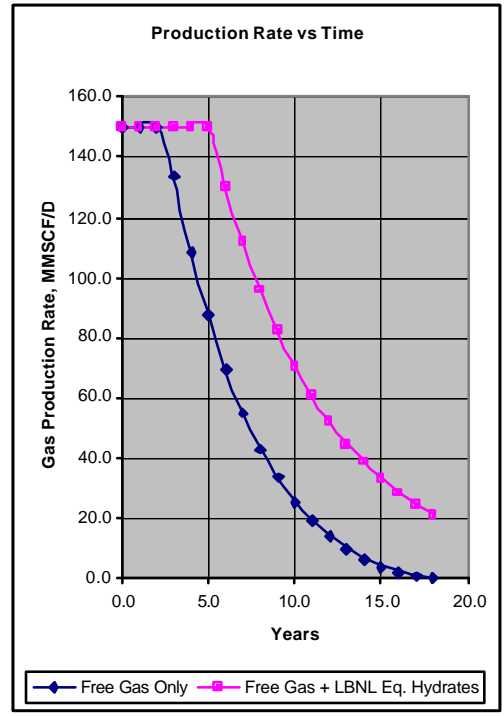

ANS Methane Hydrates Study BP/DOE/USGS

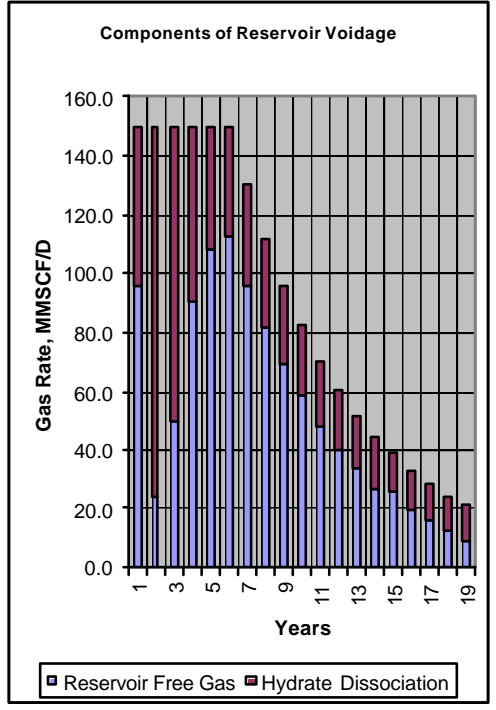

Figure 9

Pre-Phase 1 Scoping 


\section{Gas Recovery comparison}

- Significant production increase due to potential hydrate dissociation

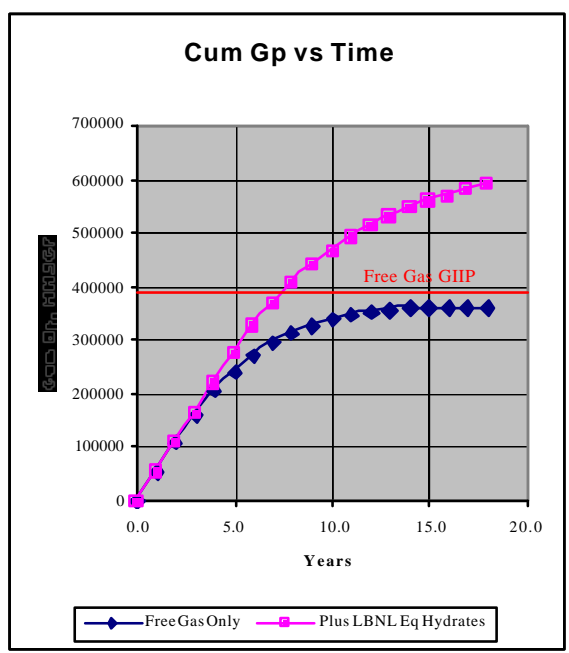

\section{Conclusions}

- Free gas performance modeled adequately, though better reservoir description is needed as a key Phase 1 deliverable.

- LBNL hydrate dissociation forecast has been suitably forecast for this scoping, and adequately incorporated into the combined forecast.

- Hydrate dissociation rates apparently controlled by $\Delta \mathrm{P}$ in early time, but limited by heat transfer capacity in later time. Additional modeling to be pursued in Phase 1.

- Scoping economics are encouraging for this free gas reservoir with hydrate support.

- Phase 1 study has been approved by BP, and will proceed as proposed. 


\subsection{CONCLUSION}

Interim conclusions only are presented at this stage in the research program. Establishing this collaborative research agreement culminates nearly three decades of hundreds of well penetrations of methane hydrate during oil production operations on ANS following the first dedicated gas hydrate coring and production testing in NW Eileen State - 02, drilled within the Eileen gas hydrate trend by Arco and Exxon in 1972. During this time, methane hydrates were known primarily as a drilling hazard. Industry has only recently considered the resource potential of conventional ANS gas during industry and government efforts in working toward an ANS gas pipeline. Consideration of the resource potential of conventional ANS gas created the industry - government alignment necessary to also consider the resource potential of the potentially huge $(40-100 \mathrm{TCF}$ in-place $)$ unconventional ANS methane hydrate accumulations beneath existing production infrastructure. The BPXA - DOE collaborative research project is designed to enable industry and government to make informed decisions regarding the resource potential of this ANS methane hydrate through the first-ever regional shallow reservoir and fluid characterization utilizing 3D seismic data, implementation of methane hydrate experiments, and design of techniques to support potential methane hydrate drilling, completion, and production operations.

The results of the collaborative BPXA-LBNL pre-Phase 1 scoping reservoir model and economics study demonstrate first-ever potential commerciality of gas production from gas hydrate across a broad regional contact from adjacent free gas depressurization. This collaborative research project will verify the size of the potential resource, determine the extent of reservoir/fluid compartmentalization, and validate potential production techniques.

\subsection{PROJECT AND RELATED REFERENCES}

Casavant, R.R. and Gross, E., 2002, Basement Fault Blocks and Subthrust Basins? A Morphotectonic Investigation in the Central Foothills and Brooks Range, Alaska, at the SPEAAPG: Western Region-Pacific Section Conference, Anchorage, Alaska, May 18-23, 2002.

Casavant, R.R. and Miller, S.R., 2002, Tectonic Geomorphic Characterization of a Transcurrent Fault Zone, Western Brooks Range, Alaska, at the SPE-AAPG: Western Region-Pacific Section Conference, Anchorage, Alaska, May 18-23, 2002.

Collett, T.S., 2001, Natural gas hydrates: resource of the twenty-first century? In M.W. Downey, J.C. Treet, and W.A. Morgan eds., Petroleum Provinces of the Twenty-First Century: American Association of Petroleum Geologist Memoir 74, p. 85-108.

Collett, T.S., 12/6/2001, MEMORANDUM: Preliminary analysis of the potential gas hydrate accumulations along the western margin of the Kuparuk River Unit, North Slope, Alaska (unpublished administrative report).

Collett et al., 2001, Modified version of a multi-well correlation section between the Cirque2 and Reindeer Island-1 wells, depicting the occurrence of the Eileen and Tarn gas hydrate and associated free-gas accumulations (unpublished administrative report). 
Collett et al., 2001, Modified version of a map that depicts the distribution of the Eileen and Tarn gas hydrate and associated free-gas accumulations (unpublished administrative report). Collett, T.S., 2002, Methane hydrate issues - resource assessment, In the Proceedings of the Methane Hydrates Interagency R\&D Conference, March 20-22, 2002, Washington, D.C., 30 p.

Collett, T.S., 2002, Energy resource potential of natural gas hydrates: Bulletin American Association of Petroleum Geologists, v. 86, no. 11, p. 1971-1992.

Collett, T.S., and Dallimore, S.R., 2002, Detailed analysis of gas hydrate induced drilling and production hazards, In the Proceedings of the Fourth International Conference on Gas Hydrates, April 19-23, 2002, Yokahama, Japan, 8 p.

Hunter, R.B., Pelka, G.J., Digert, S.A., Casavant, R.R., Johnson, R., Poulton, M., Glass, C., Mallon, K., Patil, S.L., Chukwu, G.A., Dandekar, A.Y., Khataniar, S., Ogbe, D.O., and Collett, T.S., "Resource Characterization and Quantification of Natural Gas-Hydrate and Associated Free-Gas Accumulations in the Prudhoe Bay-Kuparuk River Area on the North Slope of Alaska", presented at the Methane Hydrate Inter-Agency Conference of US Department of Energy, Washington DC, March 21-23, 2002.

Hunter, R.B., Pelka, G.J., Digert, S.A., Casavant, R.R., Johnson, R., Poulton, M., Glass, C., Mallon, K., Patil, S.L., Chukwu, G.A., Dandekar, A.Y., Khataniar, S., Ogbe, D.O., and Collett, T.S., "Resource Characterization and Quantification of Natural Gas-Hydrate and Associated Free-Gas Accumulations in the Prudhoe Bay-Kuparuk River Area on the North Slope of Alaska", at the SPE-AAPG: Western Region-Pacific Section Conference, Anchorage, Alaska, May 18-23, 2002.

Lee, M.W., 2002, Joint inversion of acoustic and resistivity data for the estimation of gas hydrate concentration: U.S. Geological Survey Bulletin 2190, 11 p.

Lewis, R.E., Collett, T.S., and Lee, M.W., 2001, Integrated well log montage for the Phillips Alaska Inc., Kuparuk River Unit (Tarn Pool) 2N-349 Well (unpublished administrative report).

Khataniar, S, Kamath, V.A., Omenihu, S.D., Patil, S.L., and Dandekar, A.Y., "Modeling and Economic Analysis of Gas Production from Hydrates by Depressurization Method", The Canadian Journal of Chemical Engineering, Volume 80, February 2002.

\subsection{Short Courses}

"Natural Gas Hydrates", By Tim Collett (USGS) and Shirish Patil (UAF), A Short Course at the SPE-AAPG: Western Region-Pacific Section Conference, Anchorage, Alaska, May 1823, 2002, Sponsored by Alaska Division of Geological and Geophysical Surveys and West Coast Petroleum Technology Transfer Council, Anchorage, Alaska. 


\subsection{LIST OF ACRONYMS AND ABBREVIATIONS}

\begin{tabular}{|c|c|}
\hline cronym & Denotation \\
\hline & Two Dimensional (seismic or reservoir data) \\
\hline 3D & Three Dimensional (seismic or reservoir data) \\
\hline AAPG & American Association of Petroleum Geologists \\
\hline AETDL & Alaska Energy Technology Development Laboratory \\
\hline ANL & Argonne National Laboratory \\
\hline ANN & Artificial Neural Network \\
\hline ANS & Alaska North Slope \\
\hline AOGCC & Alaska Oil and Gas Conservation Commission \\
\hline ASTM & American Society for Testing and Materials \\
\hline BLM & Bureau of Land Management \\
\hline $\mathrm{BP}$ & British Petroleum (BP Exploration (Alaska), Inc. \\
\hline BPXA & BP Exploration (Alaska), Inc. \\
\hline DGGS & Alaska Division of Geological and Geophysical Surveys \\
\hline DNR & Alaska Department of Natural Resources \\
\hline GEOS & UA Department of Geology and Geophysics \\
\hline GOM & Gulf of Mexico (typically referring to Chevron Gas Hydrate project JIP) \\
\hline HP & Hewlett Packard \\
\hline JBN & Johnson-Bossler-Naumann method (of gas-water relative permeabilities) \\
\hline JIP & Joint Industry Participating (group/agreement), ex. Chevron GOM project \\
\hline JNOC & Japan National Oil Corporation \\
\hline KRU & Kuparuk River Unit \\
\hline LBNL & Lawrence Berkeley National Laboratory \\
\hline MGE & UA Department of Mining and Geological Engineering \\
\hline MPU & Milne Point Unit \\
\hline NETL & National Energy Technology Laboratory \\
\hline ONGC & Oil and Natural Gas Corporation Limited (India) \\
\hline PBU & Prudhoe Bay Unit \\
\hline PNNL & Pacific Northwest National Laboratory \\
\hline SPE & Society of Petroleum Engineers \\
\hline TCF & Trillion Cubic Feet of Gas at Standard Conditions \\
\hline TCM & Trillion Cubic Meters of Gas at Standard Conditions \\
\hline UA & University of Arizona (or Arizona Board of Regents) \\
\hline UAF & University of Alaska, Fairbanks \\
\hline USGS & United States Geological Survey \\
\hline USDOE & United States Department of Energy \\
\hline VSP & Vertical Seismic Profile \\
\hline
\end{tabular}




\subsection{APPENDICES}

\subsection{APPENDIX A: Project Scope of Work}

\section{STATEMENT OF PROJECT OBJECTIVES AND SCOPE OF WORK}

Resource Characterization and Quantification of Natural Gas-Hydrate and Associated Free-Gas Accumulations in the Prudhoe Bay - Kuparuk River Area on the North Slope of Alaska

\section{PROJECT OBJECTIVES}

The primary objective of this project is to characterize, quantify and determine the commercial potential of in-place and recoverable gas-hydrate and associated free-gas resources in the Prudhoe Bay Unit (PBU), Kuparuk River Unit (KRU) and Milne Point Unit (MPU) areas on the Alaska North Slope (ANS). Limited, systematic gas hydrate reservoir characterization studies have been conducted; however, ANS gas hydrates have not been characterized by detailed reservoir analyses to determine hydrate reservoir extent, stratigraphy, structure, continuity, quality, variability and geophysical and petrophysical property distribution. This project will study these characteristics to provide practical input to reservoir and economic models, to determine the technical feasibility of gas hydrate production, and to provide leverage for exploration and field extension of the resource in the PBU, KRU, MPU areas on the ANS.

\section{PROJECT SCOPE OF WORK}

The project consists of a multi-phased, multi-year, collaborative effort to determine the technical and economic feasibility of gas hydrate and associated free gas resource development. Three phases are proposed over 4 years. The first phase focuses on reservoir characterization leading to estimates of recoverable reserves and commercial potential. This phase will also define procedures for gas hydrates drilling, data acquisition, completion and production. Phase II will integrate well, core, $\log$ and production test data from a new well, if justified by results from Phase I. This phase will extend the geologic and reservoir models and include a detailed analyses of structural control on the geothermal gradient and hydrate stability. Phase III will extend the models to full field and include additional drilling and long-term production testing if justified by Phase II results. This work will provide data and information that could lead to future Alaskan North Slope (ANS) gas hydrate pilot development efforts.

\section{PROJECT TASKS}

\section{PHASE I (BUDGET PERIOD I)}

Task 1.0 -- Research Management Plan

Develop a work breakdown structure and supporting narrative that concisely addresses the overall project as set forth in the agreement. Provide a concise summary of the 
technical objectives and technical approach for each Task and, where appropriate, for each subtask. Provide detailed schedules and planned expenditures for each Task including any necessary charts or tables, and all major milestones and decision points. The DOE Contracting Officer's Technical Representative (COR) shall have 20 calendar days from receipt of the Research Management Plan to review and provide comments to the recipient. Within 15 calendar days after receipt of DOE's comments, the recipient shall submit a final Research Management Plan to the DOE COR for review and approval.

Task 2.0 -- Project Technical Input, Expertise and Direction Recipient shall provide technical data, Alaska North Slope expertise and industry perspective to help maintain overall project objectives and synergy with other projects and research. Recipient will coordinate industry release of shallow seismic well log and other data, efficiently transfer rele vant data to universities and others and provide industry standards to the project scope of work.

Task 3.0 -- Review Data Collection Opportunities in Ongoing Drilling Operations Recipient shall work with industry development teams in the MPU, KRU, and PBU to review and enhance data gathering opportunities in gas hydrate and associated free gas horizons near ongoing development drilling operations.

Task 4.0 -- Provide Research Link to Consortium, Industry, University, Government and Others

Recipient shall serve as the clear point-of-contact research link with consortium, industry, university, government and other gas hydrate researchers. This will include coordinating research activities and maximizing synergies with consortium partners and other projects.

Subtask 4.1 -- Provide Continuity with Ongoing Gas Hydrate Research Efforts Recipient shall maintain communications and synergy with all project participants and maintain critical communication linkages with other ongoing gas hydrates research efforts (outside the project team members). This includes ongoing gas hydrates research efforts both domestically and internationally. Recipient shall ensure cooperation between various research elements within this project and work with other consortium members to ensure the dissemination and publication of research results and to facilitate discussions.

Task 5.0 -- Study Logging and Seismic Technology Development/Advances This task will provide project team members with a technical resource link to current research associated with downhole logging and shallow seismic evaluation of gas hydrate reservoirs. Recipient shall maintain familiarity and project contacts with research and technology development for downhole logging (wireline and MWD/LWD) and shallow seismic evaluation of gas hydrate reservoirs. Recipient shall maintain knowledge of gas hydrate related petrophysical/geophysical technology and transfer this information to the project team to ensure adequate, timely and efficient gathering of shallow seismic and log data from test well(s) associated project task. This task will provide interpretive reports 
and data from the analyses of shallow seismic and downhole logs from well(s) to be used in reservoir characterization (Task 6.0) and reservoir modeling (Task 11.0) tasks of the project.

Task 6.0 -- Integrate Shallow Seismic/Well Log Data to Characterize PBU-KRU Gas Hydrate Reservoir

Recipient shall integrate shallow portions of seismic and well log data released by BP and industry partners (subject to formal partner approval) to map the distribution and extent of gas hydrate and associated free gas zones in the PBU - KRU - MPU area, link the stratigraphic, structural, petrophysical, and geophysical attributes of gas hydrates within a detailed sequence stratigraphic framework, characterize gas hydrate and free gas resources within this framework, and identify the location for a test well.

Subtask 6.1 - Reservoir Characterization and Visualization

Recipient shall: (1) validate and review published stratigraphic correlations and compare well log correlations to USGS, and other work, and resolve discrepancies between models; (2) acquire representative sample or cuttings data, drilling data, wireline data and petroleum engineering information (casing, perforations, spinner logs, tracer data, temperature logs, etc.); (3) establish/optimize graphic output for well and cross-section displays; (4) normalize lithologic log responses; (5) correlate detailed stratigraphic sequences and parasequences; (6) integrate structural characterization studies and (7) build geologic reservoir and visualization model within local area of interest for input into Task 11.0 (Reservoir Modeling).

Subtask 6.2 -- Seismic Attributes and Calibration

Recipient shall delineate the extent of in-situ gas-hydrates and free gas zones based on seismic character and seismic attributes from shallow seismic reflection data, determine the nature of the relationship between occurrences of gas-hydrates and free gas based on seismic character and seismic attributes and model waveform character and 3-D shallow seismic attributes to validate gas hydrate occurrence. Recipient will calibrate gas-hydrate occurrences with shallow seismic properties on 3-D shallow seismic reflection data and develop appropriate techniques to facilitate automatic detection and characterization of potential areas of gas-hydrate production.

Subtask 6.3 -- Petrophysical and Artificial Neural Network (ANN) Modeling Recipient shall develop a neural network capable of analyzing waveform characteristics that represent a horizon and form robust templates to match waveforms through the shallow seismic volume in the region of interest. Neural networks will be used to identify and map hydrate facies through the shallow seismic volume by analyzing the morphology of wavelets within a specified horizon. The neural networks will also be used to help correlate well log signatures with shallow seismic data, to predict log properties throughout the shallow seismic volume, to invert the seismic data, and to detect features in the seismic data. Neural networks will also be used to classify well log data 
and identify the occurrence of gas hydrate even in a stratigraphically complex area. Petrophysical modeling and calibration of the well logs to shallow seismic data will help determine typical gas hydrate responses under a variety of conditions.

Task 7.0 -- Laboratory Studies in Support of Gas Hydrate Drilling, Completion and Production

Recipient shall design experiments to characterize the formation/dissociation of hydrates in porous media at or near reservoir conditions. Measurements will be carried out in the presence of fresh water and typical formation water.

Subtask 7.1 -- Characterize Gas Hydrate Equilibrium

Recipient shall generate experimental hydrate curves (P-T diagrams) for methane, ethane and standard natural gas mixtures, determine reliability of the experimental techniques and develop thermodynamic models to cover range of compositions and temperatures.

Subtask 7.2 -- Measure Gas-Water Relative Permeabilities in Gas-Hydrate $\underline{\text { Reservoirs }}$

Recipient shall determine relative permeability function relationships by conducting two-phase relative permeability experiments, quantify flow amount in multiphase state, and assess gas productivity from the hydrate bearing porous media. Relative permeability measurements on synthetic or model gas hydrate core plugs will use the unsteady-state technique with formation water-saturated core plugs, absolute permeability base, two-phase production data, pressure drop and plug dimensions using the Johnson-Bossler-Naumann (JBN) method.

Task 8.0 -- Evaluate Drilling Fluids

Recipient shall evaluate available options and design a temperature-controlled drilling mud system to ensure effective well operations and data gathering.

Subtask 8.1 -- Design Integrated Mud System for Effective Drilling, Completion and Production Operations

Recipient shall select and design an integrated mud system to maximize efficient drilling, completion and production operations in gas-hydrate bearing sediments.

\section{Subtask 8.2 -- Assess Formation Damage Prevention}

Recipient shall conduct hole erosion experiments, evaluate mud chilling systems, and conduct simple spot tests to assess formation damage due to incompatibility of native fluids and sediments with certain mud systems. The mud system identified in Subtask 8.1 may minimize formation damage during drilling resulting in enhanced borehole stability, regular borehole gauge and maximized flow potential of gas hydrate and associated free gas during production testing. 


\section{Task 9.0 -- Design Cementing Program for Gas Hydrate Test Well}

Recipient shall lab-test selected cement slurries to ensure compatibility with expected borehole conditions. This will help minimize formation damage, minimize required cement volumes, maximize flow potential and maximize cement strength and bond.

Task 10.0 -- Study Coring, Core Recovery, Core Preservation and Core

Transportation

Recipient shall study core tools, recovery techniques, preservation means and transportation methods to ensure the ability to recover an undisturbed pressurized core of gas hydrate reservoir. Recipient will work with industry and others to provide a detailed review of currently available pressurized coring tools, procedures and limitations. Recipient shall develop a detailed plan for downhole coring operations and core recovery, preservation, transportation and analyses.

\section{Task 11.0 -- Reservoir Modeling}

Recipient shall utilize data from the reservoir characterization study (Task 6.0) to build new and/or optimize existing reservoir models. The reservoir model will incorporate available gas hydrate production test data and be used to help calculate reserves, productivity and development costs for determination of project economics and progression into phase II. Recipient shall provide industry perspective to, link with, and utilize the gas hydrate reservoir models currently developed by Lawrence Berkeley National Laboratory and/or others.

Task 12.0 -- Select Candidate Areas for Well of Opportunity or Dedicated Test Well Recipient shall utilize reservoir characterization products (Task 6.0) to select best candidate areas for gas hydrate and associated free gas drilling, data gathering and production testing operations during phase II. Recipient will maximize synergies with existing and planned ANS developments, ensure safe facility access and, if necessary, collaborate with other project efforts to provide high-resolution 2D and/or 3D shallow seismic surveys in the focus area(s).

Task 13.0 -- Provide Project Commercial Evaluation and Continuation of Progression into Phase II

Recipient shall calculate project appraisal economics and risk to determine project progression or termination. An economic model based on Phase I reservoir characterization (Task 6.0) and reservoir model (Task 11.0) will be developed to aid in the assessment.

\section{$\underline{\text { PHASE II (BUDGET PERIOD II) }}$}

In accordance with Section II - Special Terms and Conditions of the Agreement, the Recipient is not authorized to proceed beyond Phase I (Budget Period I) without the Department of Energy (DOE) approval of a continuation application submitted no later than sixty (60) days prior to the end of the current budget period. 
Tentative tasks are presented for the Phase II activities. The tasks are provide to describe the generally anticipated work scope.

Under this budget period, the Recipient shall update the research management plan to reflect the current status of the project and the results of Phase I. In addition, the Recipient shall prepare a draft report that provides the environmental information necessary to satisfy requirements of the National Energy Policy Act (NEPA). Recipient is not authorized to proceed beyond Phase II - Task 1.0 without the prior written NEPA approval of the DOE National Energy Technology Laboratory (NETL) Contracting Officer.

Task 1.0 -- Research Management Plan

Develop a work breakdown structure and supporting narrative that concisely addresses the overall project as set forth in the agreement. Provide a concise summary of the technical objectives and technical approach for each Task and, where appropriate, for each subtask. Provide detailed schedules and planned expenditures for each Task including any necessary charts or tables, and all major milestone s and decision points. The DOE Contracting Officer's Technical Representative (COR) shall have 20 calendar days from receipt of the Research Management Plan to review and provide comments to the recipient. Within 15 calendar days after receipt of DOE's comments, the recipient shall submit a final Research Management Plan to the DOE COR for review and approval.

Task 2.0 -- Project Technical Input, Expertise and Direction Recipient shall provide technical data, Alaska North Slope expertise and industry perspective to help maintain overall project objectives and synergy with other projects and research. Recipient will coordinate industry release of shallow seismic well log and other data, efficiently transfer relevant data to universities and others and provide industry standards to the project scope of work.

Task 3.0 -- Review Data Collection Opportunities in Ongoing Drilling Operations Recipient shall work with industry development teams in the MPU, KRU, and PBU to review and enhance data gathering opportunities in gas hydrate and associated free gas horizons near ongoing development drilling operations.

Task 4.0 -- Provide Research Link to Consortium, Industry, University, Government and Others

Recipient shall serve as the clear point-of-contact research link with consortium, industry, university, government and other gas hydrate researchers. This will include coordinating research activities and maximizing synergies with consortium partners and other projects.

Subtask 4.1 -- Provide Continuity with Ongoing Gas Hydrate Research Efforts Recipient shall maintain communications and synergy with all project participants and maintain critical communication linkages with other ongoing gas hydrates research efforts (outside the project team members). This includes ongoing gas hydrates research efforts both domestically and 
internationally. Recipient shall ensure cooperation between various research elements within this project and work with other consortium members to ensure the dissemination and publication of research results and to facilitate discussions.

\section{Task 5.0 -- Study Logging Technology Development and Advances to Apply to Gas}

Hydrate Wells

This task will provide project team members with a technical resource link to current research associated with downhole logging and shallow seismic evaluation of gas hydrate reservoirs. Recipient shall maintain familiarity and project contacts with research and technology development for downhole logging (wireline and MWD/LWD) and shallow seismic evaluation of gas hyd rate reservoirs. Recipient shall maintain knowledge of gas hydrate related petrophysical/geophysical technology and transfer this information to the project team to ensure adequate, timely and efficient gathering of shallow seismic and log data from test well(s) associated project task. This task will provide interpretive reports and data from the analyses of shallow seismic and downhole logs from well(s) to be used in reservoir characterization and reservoir modeling tasks throughout the project.

Task 6.0 -- Reservoir Characterization of Gas Hydrates: PBU - KRU - MPU Study Recipient shall integrate shallow seismic and well log data released by BP and industry partners (subject to formal partner approval) to extend mapping the distribution and extent of the individual gas hydrate and associated free gas zones from the northwestern PBU and a portion of the KRU into the southern portion of the KRU or another portion of the PBU - KRU - MPU as dictated by regional studies and the characterization team.

Subtask 6.1 -- Structural Characterization: PBU - KRU - MPU Study

Recipient shall add a detailed analysis of the hydrate stability field and the geothermal gradient in the PBU - KRU - MPU and detailed structural analysis in a structurally updip position. A detailed study of the 3D shallow seismic data will include: (1) high resolution structural and stratigraphic analysis of methane hydrate sequences in 3D seismic data; (2) interpretation of deep structures that may control the location, orientation and physical nature of methane migration paths and reservoirs; (3) investigation of the role of deep basement fault zones across the Alaskan North Slope (ANS); (4) evaluation of the efficacy of 3-component seismic reflection (if available) to capture fracture-related anisotropy, deep physical properties, fracture orientation and density and (5) the extrapolation of " 3 -D" characterization to available 2-D data in the vicinity of the Tarn field and/or other candidate hydrate prospects adjacent to the KRU. The data will be used to modify a model from Phase I to provide a more detailed description of the hydrate stability field and the role of structural control on hydrate occurrence.

Subtask 6.2 -- Gas Hydrate Resource Visualization: PBU - KRU - MPU Study Recipient shall enhance ability to understand and appreciate the complexities of the subsurface gas hydrate occurrences and investigate 2-D and 3-D visualization and image processing strategies. 
Subtask 6.3 -- Construct Gas Hydrate Stratigraphic Reservoir Model: PBU KRU - MPU Study

Recipient shall correlate detailed stratigraphic sequences and parasequences across portions of the PBU - KRU - MPU using all available data and methodologies developed in Phase I - Task 6.0, Subtasks 6.1 - 6.3. Links will be made to the PBU geologic description from Task 6.0. The main research activities will be to develop a gas hydrate geologic reservoir model for PBU KRU - MPU and construct a geologic reservoir model for a portion of the PBU - KRU - MPU based on detailed mapping of structure, stratigraphy, and petrophysics of gas hydrate reservoir.

Task 7.0 -- Well Design Study: Productivity and Reservoir Modeling

Subtask 7.1 -- Develop Analytical, Mechanistic and Numerical Models for Gas Hydrate Production

Recipient shall use the information from the geologic characterization (Phase I, Task 6.0 and Phase II, Task 6.0) to build and/or update reservoir models to study hydrate well design. Recipient shall leverage existing modeling knowledge and technology by collaborating with LBNL and other active hydrate modeling research and code development efforts. Single well, pattern and sectional models will be used to help determine drill site, well design and predict productivity characteristics.

\section{Subtask 7.2 -- Develop Depressurization Production Model}

Recipient shall predict the performance of gas production by depressurization methods by combining generalized material balance equations with kinetics of hydrate decomposition. The work will utilize analytical equations evaluate scenarios with varying gas production rate, bottom hole pressure and initial water saturation. This sensitivity analysis will be used for initial design of the hydrate well production plan and forecast.

Subtask 7.3 -- Develop Reservoir Model Using Conditional Simulation Recipient shall develop reservoir modeling capabilities using conditional simulation. The deterministic characterization and reservoir characterization developed earlier in the project will serve as input data for this subtask. Information on pore connectivity will also be used with Truncated Gaussian Model techniques that honor conductivity constraints. Conditional simulation will be the most frequently used technique in this sub-task due to its ability to reproduce true spatial continuity.

Subtask 7.4 -- Economic Analysis/Feasibility Study of Gas Production from Gas Hydrates

Recipient shall develop an analytical model to evaluate the economic feasibility of natural gas production from a gas hydrate-free gas reservoir using depressurization techniques. The model will couple material balance, 
inflow performance relationship and intrinsic kinetics of hydrate decomposition. Sensitivity of parameters affecting rate of return will be analyzed using the developed economic model. The model will analyze feasibility of production of natural gas from ANS gas hydrate resources and determine the effect of reservoir and production parameters on the hydrate contribution.

\section{$\underline{\text { Task } 8.0 \text {-- Design Completion and Production Testing for Gas Hydrate Well }}$}

\section{Subtask 8.1 --Well Completion Prognosis}

Recipient shall develop a unique completion technique compatible with the penetrated formation. Recipient will provide the pressure drop occurring across perforations in the presence of two-phase flow and use the computed pressure drop to estimate productivity in the perforated interval. Recipient shall develop a reservoir simulator to examine the effects of two-phase flow, high velocity, gravitational forces, shape and distribution of perforations and degree of formation damage due to perforations.

\section{Subtask 8.2 -- Well Production Testing Design}

Recipient shall determine best well design and completion to optimize a production test program of up to one-year duration. Recipient shall design production testing program to best estimate inflow performance of various gas hydrate well designs.

\section{Task 9.0 -- Select Best Candidate Well of Opportunity or Dedicated Test Well}

Recipient shall utilize reservoir characterization products and other available information to select best candidate areas for gas hydrate and associated free gas drilling, data gathering and production testing operations during phase III. Recipient will maximize synergies with existing and planned ANS developments, ensure safe facility access and, if necessary, collaborate with other project efforts to provide high-resolution $2 \mathrm{D}$ and/or 3D shallow seismic surveys in the focus area(s).

Task 10.0 -- Provide Facilities and Staff for Drilling, Completion, Short Term Testing, Data Well of Opportunity or Dedicated Well

Recipient shall drill, core and log a vertical or near-vertical well and possibly one lateral well at the gas-hydrate test site area. Recipient shall attempt to core the gas-hydrate to free-gas interface and to conduct production tests.

Task 11.0 -- Provide Project Commercial Evaluation and Continuation of Progression into Phase 3

Recipient shall calculate project appraisal economics and risk to determine project progression or termination. An economic model based on Phase I and II reservoir characterization and reservoir modeling efforts and results will be developed to aid in the assessment. 


\section{PHASE III (BUDGET PERIOD III)}

In accordance with Section II - Special Terms and Conditions of the Agreement, the Recipient is not authorized to proceed beyond Phase II (Budget Period II) without the Department of Energy (DOE) approval of a continuation application submitted no later than sixty (60) days prior to the end of the current budget period.

Tentative task titles are presented for the Phase III activities. The task titles are provide to describe the generally anticipated work scope.

Under this budget period, the Recipient shall update the research management plan to reflect the current status of the project and the results of Phase II. In addition, the Recipient shall prepare a draft report that provides the environmental information necessary to satisfy requirements of the National Energy Policy Act (NEPA). Recipient is not authorized to proceed beyond Phase III - Task 1.0 without the prior written NEPA approval of the DOE National Energy Technology Laboratory (NETL) Contracting Officer.

Task 1.0 -- Research Management Plan

$\underline{\text { Task } 2.0 \text {-- Project Technical Input, Expertise and Direction }}$

Task 3.0 -- Review Data Collection Opportunities in Ongoing Drilling Operations

Task 4.0 -- Provide Research Link to Consortium, Industry, University, Government and Others

Task 5.0 -- Study Logging Technology Development and Advances to Apply to Gas Hydrate Wells

$\underline{\text { Task } 6.0 \text {-- Construct Gas Hydrate Resource Full Field Characterization }}$

Task 7.0 -- Measure Petrophysical and Other Physical Properties of Hydrate Core $\underline{\text { Samples }}$

Task 8.0 -- Gas Hydrate Decomposition Study

Task 9.0 -- Study Geotechnical Properties of Gas-Hydrate Bearing Reservoirs

Task 10.0 -- Develop Detailed Well and Full-Field Reservoir Model

Task 11.0 -- Select Additional Candidate Well of Opportunity or Dedicated Test Well

Task 12.0 -- Provide Facilities and Staff for Drilling, Completion, Long Term Testing, Data Well of Opportunity or Dedicated Well 
Task 13.0 -- Evaluate Commerciality and Continuation of Project into Pilot Development

\section{PROJECT DELIVERABLES}

The periodic, topical, and final reports shall be submitted in accordance with the attached "Federal Assistance Reporting Checklist" and the instructions accompanying the checklist.

The following report is required 30 days after award of the Cooperative Agreement.

Task 1.0 - Research Management Plan

In addition to the required reports, the recipient shall submit informal status reports directly to the COR. These are preferred monthly with short descriptions of successes, problems, advances or other general project status information. The report should not exceed one (1) page in length and be submitted via e-mail.

The Recipient shall also provide the following to DOE:

A copy of all non-proprietary data, models, protocols, maps and other information generated under the cooperative agreement, when requested by DOE, in a format mutually agreed upon by DOE and the Recipient.

\section{PROJECT BRIEFINGS/TECHNICAL PRESENTATIONS}

1. The Recipient shall prepare and present, at the COR's NETL facility located in Pittsburgh, PA or Morgantown, WV, an overview of the entire project at a kickoff meeting at a time to be arranged by the COR. The overview shall include a discussion of the technical approach, project management and a detailed breakdown of the project budget.

2. The Recipient shall provide and present a technical paper/presentation on the project work effort at a DOE/NETL sponsored Review Meeting or Workshop (one per fiscal year) to be held at a location to be determined. (For costing purposes, Pittsburgh, PA should be used as the location.)

3. The Recipient shall prepare a detailed final briefing for presentation to the COR at the COR's facility located in Pittsburgh, PA or Morgantown, WV. 


\subsection{APPENDIX B: Project Task Schedules and Milestones}

\subsubsection{U.S. Department of Energy Milestone Log}

Program/Project Title: DE-FC26-01NT41332: Resource Characterization and Quantification of Natural Gas-Hydrate and Associated Free-Gas Accumulations in the Prudhoe Bay - Kuparuk River Area on the North Slope of Alaska

\begin{tabular}{|c|c|c|c|c|}
\hline $\begin{array}{c}\text { Identification } \\
\text { Number }\end{array}$ & Description & $\begin{array}{c}\text { Planned } \\
\text { Completion } \\
\text { Date }\end{array}$ & $\begin{array}{c}\text { Actual } \\
\text { Completion } \\
\text { Date }\end{array}$ & Comments \\
\hline Task 1.0 & Research Management Plan & $12 / 02$ & $12 / 02$ & Subcontracts Completed \\
\hline Task 2.0 & $\begin{array}{l}\text { Provide Technical Data and } \\
\text { Expertise }\end{array}$ & $\begin{array}{l}\text { MPU: } 12 / 02 \\
\text { PBU: } 6 / 03 * \\
\text { KRU: unk* }\end{array}$ & $\begin{array}{l}\text { MPU: 12/02 } \\
\text { PBU: * } \\
\text { KRU: * }\end{array}$ & $\begin{array}{l}\text { Ongoing, See Technical } \\
\text { Progress Report } \\
\text { Description }\end{array}$ \\
\hline Task 3.0 & $\begin{array}{l}\text { Wells of Opportunity Data } \\
\text { Acquisition }\end{array}$ & $\begin{array}{l}\text { Ongoing to } \\
12 / 03 \text { or } \\
\text { beyond } * *\end{array}$ & Ongoing & $\begin{array}{l}\text { Ongoing, See Technical } \\
\text { Progress Report } \\
\text { Description }\end{array}$ \\
\hline Task 4.0 & Research Collaboration Link & $\begin{array}{l}\text { Ongoing to } \\
12 / 03 \text { or } \\
\text { beyond } * *\end{array}$ & Ongoing & $\begin{array}{l}\text { Ongoing, See Technical } \\
\text { Progress Report } \\
\text { Description }\end{array}$ \\
\hline Subtask 4.1 & Research Continuity & Ongoing & Ongoing & \\
\hline Task 5.0 & $\begin{array}{l}\text { Logging and Seismic Technology } \\
\text { Advances }\end{array}$ & $\begin{array}{l}\text { Ongoing to } \\
12 / 03 \text { or } \\
\text { beyond** }\end{array}$ & & $\begin{array}{l}\text { Ongoing, See Technical } \\
\text { Progress Report } \\
\text { Description }\end{array}$ \\
\hline Task 6.0 & $\begin{array}{l}\text { Reservoir and Fluids } \\
\text { Characterization Study }\end{array}$ & $10 / 04 * *$ & & $\begin{array}{l}\text { Interim Results to also be } \\
\text { presented }\end{array}$ \\
\hline Subtask 6.1 & $\begin{array}{l}\text { Characterization and } \\
\text { Visualization }\end{array}$ & $10 / 04 * *$ & & $\begin{array}{l}\text { Interim Results to also be } \\
\text { presented }\end{array}$ \\
\hline Subtask 6.2 & $\begin{array}{l}\text { Seismic Attributes and } \\
\text { Calibration }\end{array}$ & $10 / 04 * *$ & & $\begin{array}{l}\text { Interim Results to also be } \\
\text { presented }\end{array}$ \\
\hline Subtask 6.3 & $\begin{array}{l}\text { Petrophysics and Artificial Neural } \\
\text { Net }\end{array}$ & $10 / 04 * *$ & & $\begin{array}{l}\text { Interim Results to also be } \\
\text { presented }\end{array}$ \\
\hline Task 7.0 & $\begin{array}{l}\text { Laboratory Studies for Drilling, } \\
\text { Completion, Production Support }\end{array}$ & $6 / 04$ & & \\
\hline Subtask 7.1 & $\begin{array}{l}\text { Characterize Gas Hydrate } \\
\text { Equilibrium }\end{array}$ & $6 / 04$ & & \\
\hline Subtask 7.2 & $\begin{array}{l}\text { Measure Gas-Water Relative } \\
\text { Permeabilities }\end{array}$ & $6 / 04$ & & \\
\hline Task 8.0 & Evaluate Drilling Fluids & $6 / 04$ & & \\
\hline Subtask 8.1 & Design Mud System & $11 / 03$ & & \\
\hline Subtask 8.2 & Assess Formation Damage & $5 / 04$ & & \\
\hline
\end{tabular}




\begin{tabular}{|l|l|l|l|l}
\hline Task 9.0 & Design Cement Program & $10 / 04$ & & \\
\hline Task 10.0 & Study Coring Technology & $2 / 04$ & & \\
\hline Task 11.0 & Reservoir Modeling & $10 / 04^{* *}$ & & $\begin{array}{l}\text { Interim Results to also be } \\
\text { presented }\end{array}$ \\
\hline Task 12.0 & $\begin{array}{l}\text { Select Drilling Location and } \\
\text { Candidate }\end{array}$ & $10 / 04^{* *}$ & & \\
\hline Task 13.0 & $\begin{array}{l}\text { Project Commerciality \& } \\
\text { Progression Assessment }\end{array}$ & $10 / 04^{* *}$ & & $\begin{array}{l}\text { Interim Results to also be } \\
\text { presented }\end{array}$ \\
\hline
\end{tabular}

* Completion date estimate dependent upon industry partner agreement for release of seismic data

** Anticipated completion dates beyond 12/31/03 will require no-cost (and possibly some-cost) time-extension due to administrative delays of contract 


\subsubsection{U.S. Department of Energy Milestone Plan}

(original submitted on DOE F4600.3)

DOEFAONOS*

DPST

cropestom
U.S. LEARTMENT OFENERGY

\section{FEDERAL ASSISTANCE MILESTONE PLAN}

OMBEAndalischore Stamat ous conird Ma $1910 \mathrm{an}$

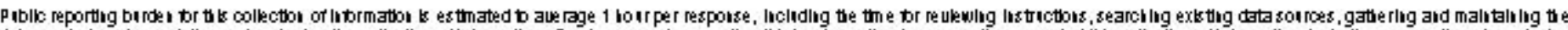

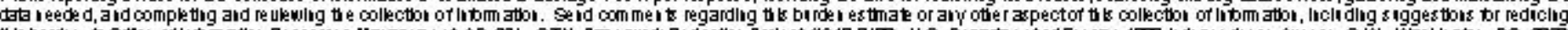

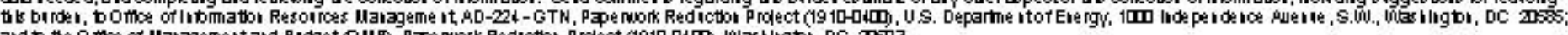

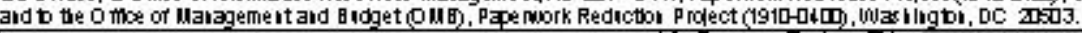

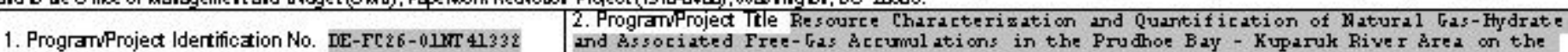
3. Penomer (Name, म्वतress) North 31 ope of $\mathrm{Al} 2 \mathrm{sk} 2$

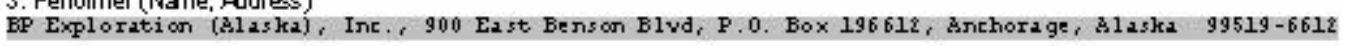

4. ProgramiProject Start Date 10/2z/02*

5. ProgramiProjed Completion Date 12/31/05*

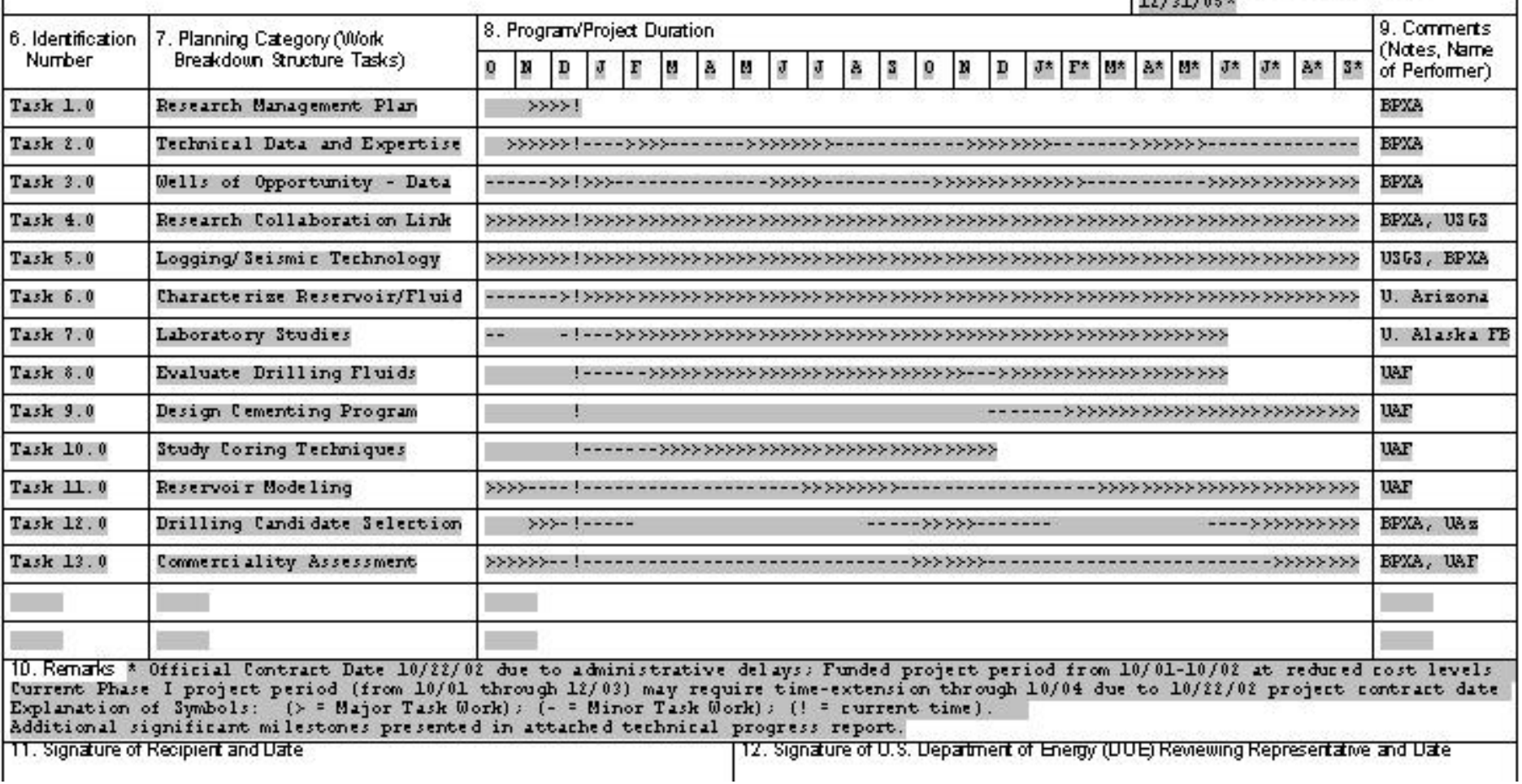




\title{
9.3 APPENDIX C: Project Budgets for BP and Subcontractors (UA and UAF)
}

\subsubsection{BP Exploration (Alaska), Inc. Original Project Budget Pages}

9.3.1.1 BP Exploration (Alaska), Inc. Original Project Budget Year 1, Phase 1

BP Budget Phase 1 (year 1) Tasks: 1.1, 1.2, 1.3, 1.4, 1.5 (25\%)

Hours DOE Cost BP in-kind Total FY2001

Personnel:

Robert Hunter - Project manager and Principal Investigator

Gary Pelka - geologist, BP Alaska Exploration*

Scott Digert - engineer, BP Alaska Gas*

Donna Douglas - accountant, BP accounting

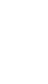

*Subject to availability; hours contributed at BP-Expense, not in-kind calculation

Travel:

DOE Kickoff meeting

Project meetings

Technical Conferences

\section{Supplies:}

Data media and distribution

Geophysical Software via Agreement with Landmark Corporation**

Geophysical Workstations Donation to University of Arizona (8 workstations )

\section{Contractual:}

Reservoir Modeling

\begin{tabular}{|c|c|c|c|c|c|}
\hline $1304 \$$ & 119,316 & $\$$ & 39,772 & $\$$ & 159,088 \\
\hline $186 \$$ & - & $\$$ & - & $\$$ & - \\
\hline $186 \$$ & - & $\$$ & - & $\$$ & - \\
\hline $78 \$$ & 4,290 & & & $\$$ & 4,290 \\
\hline $1754 \$$ & 123,606 & $\$$ & 39,772 & $\$$ & 163,378 \\
\hline$\$$ & 14,000 & $\$$ & - & $\$$ & 14,000 \\
\hline
\end{tabular}

Other:

Contribution of shallow seismic data from 3D surveys (subject to partner approval) (see valuation discussion section behind Volume III cover)

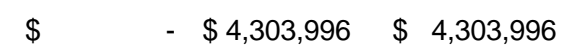

Total Directs

Total Indirects

* \$750,000 Landmark Corporation Grant to University of Arizona carried in BP budget to recognize BP facilitation of this software Grant Grant is technically a Landmark Corporation in-kind contribution. Grant herein attributed to BP in-kind Landmark Corp. not a formal Research Collaborator 
9.3.1.2 BP Exploration (Alaska), Inc. Original Project Budget Year 2, Phase 1

BP Budget Phase 1 (year 2) Tasks: 1.1, 1.2, 1.3, 1.4, 1.5 (75\%), 1.6 Hours DOE Cost BP in-kind Total FY2002

\section{Personnel:}

Robert Hunter - Project manager and Principal Investigator

Gary Pelka - geologist, BP Alaska Exploration*

Scott Digert - engineer, BP Alaska Gas*

BP Staff commercial analyst*

Donna Douglas - accountant, BP accounting

*Subject to availability; hours contributed at BP-Expense, not in-kind calculation

Travel:

Project meetings

Technical Conferences

Supplies:

Data media and distribution

\section{Contractual:}

Reservoir modeling

$\begin{array}{rrrrrr}1304 \$ & 124,089 & \$ & 41,363 & \$ & 165,452 \\ 258 \$ & - & \$ & - & \$ & - \\ 258 \$ & - & \$ & - & \$ & - \\ 60 \$ & - & \$ & - & \$ & - \\ 48 \$ & 2,640 & & & \$ & 2,640 \\ 1928 \$ & 126,729 & \$ & 41,363 & \$ & 168,092\end{array}$

$\$ 14,000 \$ \quad-\$ 14,000$

$\$ 5,000 \quad \$ \quad 5,000$

$80 \$ \quad 7,808 \quad \$ \quad 1,952 \quad \$ \quad 9,760$

Other:

$\begin{array}{crrrrrr}\text { Total Directs } & \$ & 153,537 & \$ & 43,315 & \$ & 196,852 \\ \text { Total Indirects } & \$ & - & \$ & - & \$ & \\ & & & & & & \\ \text { ect (BP) Year 2 } & \$ & 153,537 & \$ & 43,315 & \$ & 196,852\end{array}$

$\$$

Total Amount Request - InKind, Year 2 110,222

Running Subtotal Amount Request - InKind, Years 1 and 2 2) 


\subsubsection{BP Exploration (Alaska), Inc. Original Project Budget Year 3, Phase 2}

BP Budget Phase 2 (year 3) Tasks: 2.1, 2.2, 2.3, 2.4, 2.5, 2.6, 2.7 Hours $\quad$ DOE Cost BP in-kind Total FY2003

\section{Personnel:}

Robert Hunter - Project manager and Principal Investigator

Gary Pelka - geologist, BP Alaska Exploration*

Scott Digert - engineer, BP Alaska Gas *

BP staff drilling engineer (432), commercial analyst (60) and tech assistant (40)*

Donna Douglas - accountant, BP accounting

*Subject to availability; hours contributed at BP-Expense, not in-kind calculation total

Travel:

Project meetings

Technical Conferences

\section{Supplies:}

Data media and distribution

$\$ 5,000$

\begin{tabular}{|c|c|c|c|c|c|}
\hline $1304 \$$ & 129,052 & $\$$ & 43,017 & $\$$ & 172,070 \\
\hline $350 \$$ & & $\$$ & & $\$$ & \\
\hline $350 \$$ & & $\$$ & - & $\$$ & \\
\hline 532 & & $\$$ & - & $\$$ & \\
\hline 4 & 2,640 & & & $\$$ & 2,640 \\
\hline 84 & 131,692 & $\$$ & 43,017 & $\$$ & 174,710 \\
\hline
\end{tabular}

$\$ 14,000 \$$

- $\$ 14,000$

Contractual:

Reservoir modeling

$60 \$ 5,856 \$ 1,464 \$ \quad 7,320$

Other:

Data gathering on well of opportunity (cost estimate subject to scope and charge changes): $\$ 300 \mathrm{~K}$ wireline logging suite; $\$ 150 \mathrm{~K}$ Vertical Seismic Profile; $\$ 450 \mathrm{~K}$ coring; $\$ 800 \mathrm{~K}$ rig time $\$ 800 \mathrm{~K}$ drill stem test

Total Directs

Total Indirects

Total Project (BP) Year 3
$\$ 2,636,548 \quad \$ \quad 44,481 \quad \$ 2,681,030$

$\$$

$-\$$

$\$$

$\$ 2,636,548 \quad \$ \quad 44,481 \quad \$ 2,681,030$

Total Amount Request - InKind, Year 3 \$2,592,067

Running Subtotal Amount Request - InKind, Years 1, 2, and $3 \$(2,249,945)$

*** Significant BP staff time not included herein as in-kind contribution

Potential for additional in-kind contribution from other research collaborators 


\subsubsection{BP Exploration (Alaska), Inc. Original Project Budget Year 4, Phase 3}

BP Budget Phase 3 (year 4) Tasks: 3.1, 3.2, 3.3, 3.4, 3.5, 3.6, 3.7 Hours $\quad$ DOE Cost BP in-kind Total FY2004

\section{Personnel:}

Robert Hunter - Project manager and Principal Investigator

Gary Pelka - geologist, BP Alaska Exploration*

Scott Digert - engineer, BP Alaska Gas*

BP staff drilling engineer (432), commercial analyst (60), and Tech Assistant (80)*

Donna Douglas - accountant, BP accounting

\footnotetext{
*Subject to availability; hours contributed at BP-Expense, not in-kind calculation
}

Travel:

Project meetings

Technical Conferences

\section{Supplies:}

Data media and distribution

\section{Contractual:}

Reservoir modeling

Other:

Drill and test well (cost estimate subject to scope and charge changes):

$\$ 3,000 \mathrm{~K}$ Drill and complete hydrate test well and lateral

$\$ 300 \mathrm{~K}$ wireline logging suite; $\$ 150 \mathrm{~K}$ Vertical Seismic Profile; $\$ 450$ coring;

$\$ 2,600 \mathrm{~K}$ long term production test

Total Directs

Total Indirects

Total Project (BP) Year 4

\begin{tabular}{|c|c|c|c|c|c|}
\hline $1304 \$$ & 134,214 & $\$$ & 44,738 & $\$$ & 178,952 \\
\hline $350 \$$ & - & & & $\$$ & \\
\hline $350 \$$ & - & & & $\$$ & \\
\hline $572 \$$ & - & & & $\$$ & . \\
\hline 48 & 2,640 & & & $\$$ & 2,640 \\
\hline 2624 & 136,854 & $\$$ & 44,738 & $\$$ & 181,592 \\
\hline
\end{tabular}

$\$ 14,000 \$ \quad-\$ 14,000$

Total Amount Request - InKind, Year $4 \$ 6,430,508$

Running Subtotal Amount Request - InKind, Years 1, 2, 3, and 4 \$4,180,563

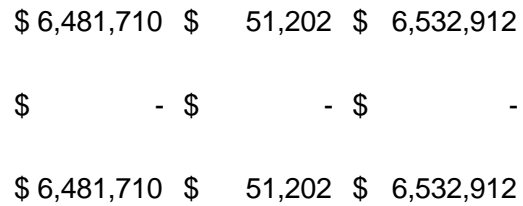

*** Significant BP staff time not included herein as in-kind contribution

Potential for additional in-kind contribution from other research collaborators 


\subsubsection{BP Exploration (Alaska), Inc. Original Project Budget Total Project}

BP Budget Total Project

Personnel:

Robert Hunter - Project manager and Principal Investigator

Gary Pelka - geologist, BP Alaska Exploration*

Scott Digert - engineer, BP Alaska Gas*

BP staff drilling engineer (432), commercial analyst (60), and Tech A ssistant (80)*

Donna Douglas - accountant, BP accounting

*Subject to availability; hours contributed at BP-Expense, not in-kind calculation

Travel:

Project meetings

Technical Conferences

\section{Supplies:}

Data media and distribution

Geophysical Software via Agreement with Landmark Corporation**

Geophysical Workstations Donation to University of Arizona (8 workstations)

\section{Contractual:}

Reservoir modeling

\section{Other:}

Drill and test well (cost estimate subject to scope and charge changes):

$\$ 3,000 \mathrm{~K}$ Drill and complete hydrate test well and lateral

\$300K wireline logging suite; \$150K Vertical Seismic Profile; $\$ 450$ coring;

$\$ 2,600 \mathrm{~K}$ long term production test

Shallow portions of 3D seismic surveys (in-kind contributions)
Hours DOE Cost BP in-kind Total 
9.3.2 University of Arizona (Tucson) Original Project Budget Pages

9.3.2.1 University of Arizona (Tucson) Original Project Budget Year 1

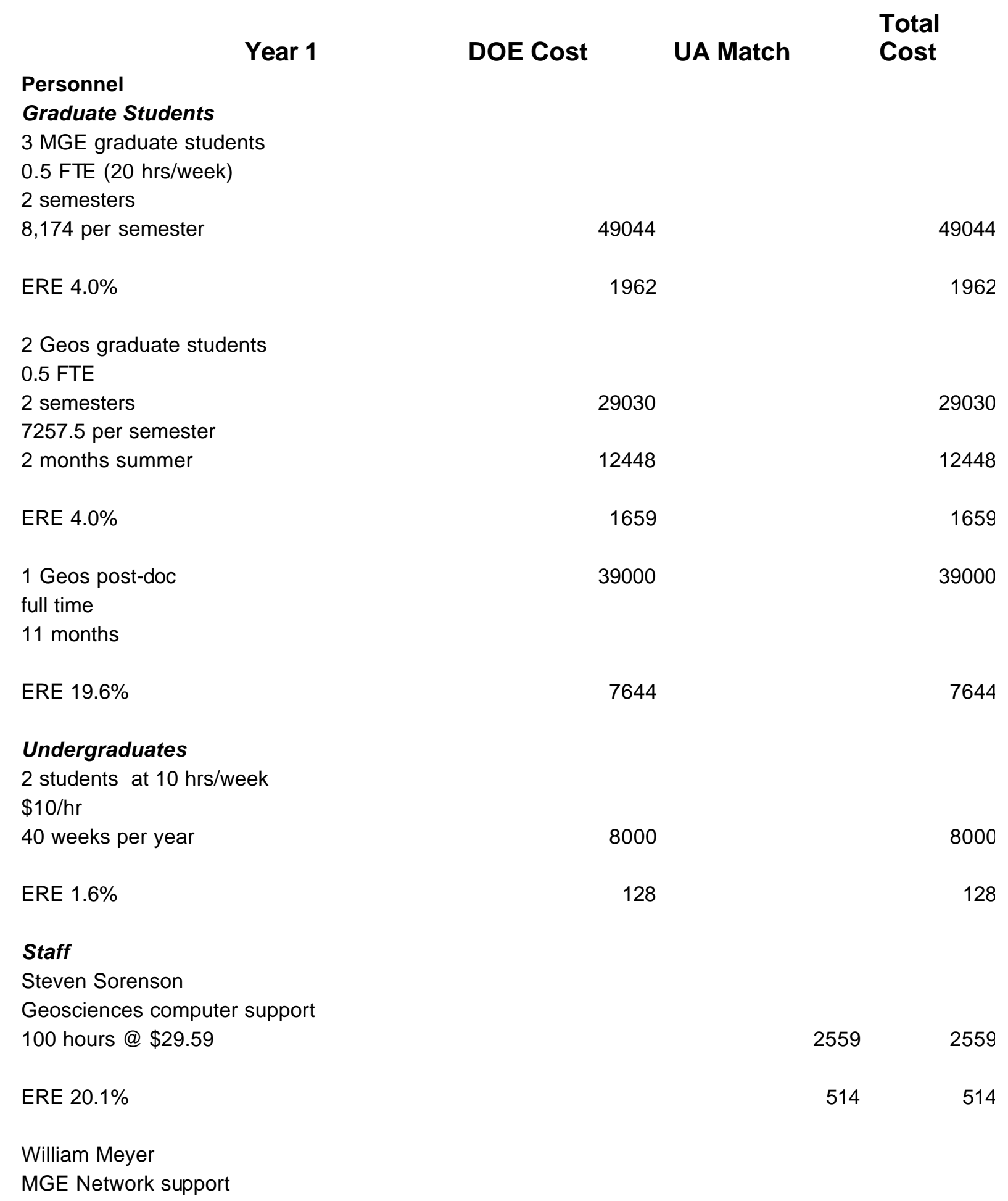


William Meyer

MGE Network support

50 hours @ \$25.72/hr

ERE $20.1 \%$

MGE computer support

\section{Faculty}

Robert Casavant

Research Assistant Professor

Project manager

Fiscal year

80000

80000

ERE $19.6 \%$

Roy Johnson

Geoscience

$\$ 45.20 / \mathrm{hr}$ for $160 \mathrm{hrs}$

ERE 19.6\%

Roy Johnson

Charles Glass

MGE

$\$ 48.31 / \mathrm{hr}$ for $120 \mathrm{hrs}$

ERE 19.6\%

Charles Glass

Mary Poulton

1 month summer 
Mary Poulton

ERE $19.6 \%$

\section{Operations}

Geosciences Department

(3D graphics card, 2 21" monitors, DLT Tape drive computer support, paper, publications

data storage media, maps, phone, copies,

photo services)

MGE Department

(3D graphics card, 21" monitor, computer support data storage media, maps, phone, copies, photo services, addition of $100 \mathrm{Mb}$ lines

publications, paper, visualization software)

Consultants

Kenneth Mallon

80 hours * $\$ 100 / \mathrm{hr}$

2 trips per year

$\$ 1,000$ travel per trip

$\$ 1,000$ per diem for 2 weeks

20000

20000

40000

Project team meeting

room rental, photocopying, food, AV

4400

4400

Seminar series and local team coordination

1000

1000

photocopying, $\mathrm{AV}$, food

Total Operations

68400

Travel

Kick-off meeting COR-NETL

1 person

1200

1200

\section{Conference attendance}

6 graduate students

1,200 per trip

3 faculty $\times 2$ trips each

1200 per trip 
Total Travel

Total Direct Costs

\section{Capital}

Geosciences

Sun 3D workstation

Disk drives $4{ }^{*} 1320$

HP Color Plotter

MGE

$\mathrm{PC}$, dual processor $1.5 \mathrm{GHz}$

1 GB Ram, 60 GB hard drive for SMT software 48 " color plotter

Total Capital

51.5\% Indirect on Direct Costs

Total UA Project Cost Year 1
15600

15600

363564

10000

10000

5280

5280

7500

5000

5000

9000

36780

36780

187236

25862

213097

587580

663658 
9.3.2.2 University of Arizona (Tucson) Original Project Budget Year 2

\section{Year 2}

( $4 \%$ increase over year 1 )

Personnel

\section{Graduate Students}

3 MGE graduate students

51006

51006

0.5 FTE (20 hrs/week)

2 semesters

8,174 per semester

ERE $4.0 \%$

2040

2040

2 Geos graduate students

0.5 FTE

2 semesters

30191

7257.5 per semester

2 months summer

12946

12946

ERE $4.0 \%$

1 Geos post-doc

40560

40560

full time

11 months

ERE $19.6 \%$

\section{Undergraduates}

2 students at $10 \mathrm{hrs} /$ week

$\$ 10 / \mathrm{hr}$

40 weeks per year

8320

8320

ERE $1.6 \%$

\section{Staff}

Steven Sorenson

Geosciences computer support

100 hours @ \$29.59

William Meyer

MGE Network support

50 hours @ \$25.72/hr 
William Meyer

MGE Network support

50 hours @ \$25.72/hr

MGE computer support

$\$ 12 / \mathrm{hr}, 10 \mathrm{hrs} / \mathrm{wk}, 52 \mathrm{wks} / \mathrm{yr}$

6490

6490

ERE $1.6 \%$

Faculty

Robert Casavant

Research Associate Professor

Project manager

Fiscal year

83200

83200

ERE19.6\%

16307

16307

Roy Johnson

Geoscience

$45.20 / \mathrm{hr}$ for $160 \mathrm{hrs}$

7521

7521

ERE $19.6 \%$

180 hrs @ 45.20/hr

ERE 19.6\%

Charles Glass

MGE

$\$ 48.31 / \mathrm{hr}$ for $120 \mathrm{hrs}$

ERE 19.6\%

Charles Glass

MGE

$\$ 48.31 / \mathrm{hr}$ for $50 \mathrm{hrs}$

Mary Poulton

1 month summer

$\$ 60.29 / \mathrm{hr}$ for $160 \mathrm{hrs}$ 
ERE $19.6 \%$

Total Personnel

290783

\section{Operations}

Geosciences Department

(computer support, paper, publications

data storage media, maps, phone, copies, photo services)

10400

15000

Seismic processing \& interpretation s/w

MGE Department

(computer support, paper, publications data storage media, maps, phone, copies, photo services, software maintenance)

31425

322209

10400

15000

10000

10000
20800

20800

41600

Project team meeting

room rental, photocopying, food, AV

4576

4576

Seminar series and team coordination

photocopying, AV, food

1040

1040

Total Operations

61816

20800

82616

\section{Travel}

Contractors meeting

1 person

1248

1248

\section{Conference attendance}

6 graduate students

1,200 per trip

3 faculty, 2 trips each

1,200 per trip

Total Travel 
9.3.2.3 University of Arizona (Tucson) Original Project Budget Year 3

\section{Year 3}

Personnel

Graduate Students

3 MGE graduate students

0.5 FTE (20 hrs/week)

2 semesters

8,174 per semester

ERE $4.0 \%$

2 Geos graduate students

$0.5 \mathrm{FTE}$

2 semesters

7257.5 per semester

2 months summer

ERE $4.0 \%$

1 Geos post-doc

full time

11 months

ERE $19.6 \%$

\section{Undergraduates}

2 students at $10 \mathrm{hrs} /$ week

$\$ 10 / \mathrm{hr}$

40 weeks per year

ERE $1.6 \%$

\section{DOE Cost UA Match}

(4\% increase over year 2$)$

\section{Total Cost}

53046

2122

31399

13464

1795

42182

8268

\section{Staff}

Steven Sorenson

Geosciences computer support

100 hours @ \$29.59

ERE $20.1 \%$

William Meyer

MGE Network support

50 hours @ \$25.72/hr

ERE $20.1 \%$
8653

8653

138
8268

53046

2122

31399

13464

1795

42182

2768

2768

556

556

1391

1391

280 
William Meyer

MGE Network support

50 hours @ \$25.72/hr

ERE $20.1 \%$

MGE computer support

$\$ 12 / \mathrm{hr}, 10 \mathrm{hrs} / \mathrm{wk}, 52 \mathrm{wks} / \mathrm{yr}$

ERE $1.6 \%$

\section{Faculty}

Robert Casavant

Research Assistant Professor

Project manager

Fiscal year

Roy Johnson

Geoscience

$\$ 45.20 / \mathrm{hr}$ for $160 \mathrm{hrs}$

ERE $19.6 \%$

Roy Johnson

Geoscience

$\$ 45.20 / \mathrm{hr}$ for $180 \mathrm{hrs}$

8800

8800

ERE $19.6 \%$

Charles Glass

MGE

$\$ 48.31 / \mathrm{hr}$ for $120 \mathrm{hrs}$

6270

6270

ERE 19.6\%

Charles Glass

MGE

$\$ 48.31 / \mathrm{hr}$ for $50 \mathrm{hrs}$

Mary Poulton

1 month summer

$\$ 60.29 / \mathrm{hr}$ for $160 \mathrm{hrs}$ 
Mary Poulton

1 month summer

$\$ 60.29 / \mathrm{hr}$ for $180 \mathrm{hrs}$

ERE $19.6 \%$

Total Personnel

\section{Operations}

Geosciences Department

(computer support, paper, publications

data storage media, maps, phone, copies, photo services)

10816

10816

Seismic processing \& interpretation $\mathrm{s} / \mathrm{w}$

15000

15000

MGE Department

(computer support, paper, publications

data storage media, maps, phone, copies,

photo services, software maintenance)

10816

10816

Consultants

Kenneth Mallon

80 hours * $\$ 100 / \mathrm{hr}$

2 trips per year

$\$ 1,000$ travel per trip

$\$ 1,000$ per diem for 2 weeks

21632

21632

43264

Project Team Meeting

1 meeting per year

(room rental, photocopying, food, AV,

Seminar series and team coordination

photocopying, AV, food

Travel

Contractors meeting

\section{Conference attendance}

6 graduate students

3 faculty, 2 trips each 
Total Travel

Total Direct Costs

$51.5 \%$ Indirect on Direct Costs

Total UA Project Cost Year 3
16873

383392

197447

580839
16873

54314 437706

27972

225419

82286 
9.3.2.4 University of Arizona (Tucson) Original Project Budget Year 4

\section{Year 4 DOE Cost UA Match}

Total Cost

Personnel

(4\% increase over year 3 )

\section{Graduate Students}

3 MGE graduate students

0.5 FTE (20 hrs/week)

2 semesters

8,174 per semester

ERE $4.0 \%$

2 Geos graduate students

$0.5 \mathrm{FTE}$

2 semesters

7257.5 per semester

14002

14002

ERE $4.0 \%$

1 Geos post-doc

43870

43870

full time

11 months

ERE 19.6\%

\section{Undergraduates}

2 students at $10 \mathrm{hrs} /$ week

$\$ 10 / \mathrm{hr}$

40 weeks per year

8999

8999

ERE $1.6 \%$

\section{Staff}

Steven Sorenson

Geosciences computer support

100 hours @ \$29.59

William Meyer

MGE Network support

50 hours @ \$25.72/hr 
William Meyer

MGE Network support

50 hours @ \$25.72/hr

1447

1447

ERE $20.1 \%$

291

MGE computer support

$\$ 12 / \mathrm{hr}, 10 \mathrm{hrs} / \mathrm{wk}, 52 \mathrm{wks} / \mathrm{yr}$

7019

7019

ERE $1.6 \%$

\section{Faculty}

Robert Casavant

Research Assistant Professor

Project manager

Fiscal year

89989

89989

ERE19.6\%

17638

17638

Roy Johnson

Geoscience

$\$ 45.20 / \mathrm{hr}$ for $160 \mathrm{hrs}$

ERE $19.6 \%$

Roy Johnson

Geoscience

$\$ 45.20 / \mathrm{hr}$ for $180 \mathrm{hrs}$

9152

9152

ERE 19.6\%

1794

1794

Charles Glass

MGE

$\$ 48.31 / \mathrm{hr}$ for $120 \mathrm{hrs}$

ERE $19.6 \%$

Charles Glass

MGE

$\$ 48.31 / \mathrm{hr}$ for $50 \mathrm{hrs}$

Mary Poulton

1 month summer

$\$ 60.29 / \mathrm{hr}$ for $160 \mathrm{hrs}$ 
Mary Poulton

1 month summer

$\$ 60.29 / \mathrm{hr}$ for $180 \mathrm{hrs}$

ERE $19.6 \%$

Total Personnel

\section{Operations}

Geosciences Department

(computer support, paper, publications data storage media, maps, phone, copies, photo services)

MGE Department (computer support, paper, publications data storage media, maps, phone, copies, photo services, software maintenance

Consultants

Kenneth Mallon

40 hours * $\$ 100 / \mathrm{hr}$

1 trip

$\$ 1,000$ travel per trip

$\$ 1,000$ per diem for 1 weeks

Project Team Meeting

1 workshops per year

(room rental, photocopying, food, AV,

Seminar series and team coordination

photocopying, AV, food

Report preparation

\section{Travel}

Contractors meeting

\section{Conference attendance}


6 graduate students

1,200 per trip

3 faculty, 2 trips each

1200 per trip

8099

8099

Total Travel

17548

17548

Total Direct Costs

384880

40739

425619

$51.5 \%$ Indirect on Direct Costs

198213

20980

219194

Total UA Project Cost Year 4

9.3.2.5 University of Arizona (Tucson) Original Project Budget, Total Project

Total UA Project Cost, All Years

Year DOE Cost UA Match Total Cost

$\begin{array}{llll}1 & 587580 & 76078 & 663538\end{array}$

$2 \quad 558767 \quad 79121 \quad 622557$

$3 \quad 580839 \quad 82286 \quad 663125$

$4 \quad 583093 \quad 61719 \quad 634587$

Total $\quad 2310279 \quad 299205 \quad 2583807$

rbh Calc from yearly totals

\begin{tabular}{lrrrr} 
Year & \multicolumn{4}{c}{ DOE Cost UA Match Total Cost } \\
& 1 & 587580 & 76078 & 663658 \\
& 2 & 558767 & 79121 & 637888 \\
& 3 & 580839 & 82286 & 663125 \\
& 4 & 583093 & 61719 & 644812 \\
Total & & 2310279 & 299205 & 2609484
\end{tabular}

$\begin{array}{ccc}\text { Calc Total Difference \% Total } \\ 663658 & 0 & 0.00 \\ 637888 & 0 & 0.00 \\ 663125 & 0 & 0.00 \\ 644812 & 0 & 0.00 \\ 2609484 & 0 & 0.00 \\ \text { TOTAL } & 0 & \end{array}$


9.3.3 University of Alaska Fairbanks Original Project Budget Pages

\subsubsection{University of Alaska Fairbanks Original Project Budget Year 1}

Year One Budget - S. Patil BP/DOE

\begin{tabular}{|c|c|c|c|}
\hline $\begin{array}{l}\text { Personne } \\
\text { Senior }\end{array}$ & \multicolumn{2}{|c|}{ \# pay periods } & cost \\
\hline & Patil & 4 & $\$ 10,667$ \\
\hline & Khataniar & 2 & $\$ 5,814$ \\
\hline & Dandekar & 2 & $\$ 5,472$ \\
\hline & Chukwu & 2 & $\$ 7,476$ \\
\hline & Post Doc & 26 & $\$ 43,862$ \\
\hline Total sal & & & $\$ 73,291$ \\
\hline \multicolumn{2}{|c|}{ Fringe benefits } & & $\$ 20,595$ \\
\hline \multirow[t]{4}{*}{ Others } & Grad student 1 & & $\$ 15,181$ \\
\hline & Grad student 2 & & $\$ 15,181$ \\
\hline & Grad student 3 & & $\$ 15,181$ \\
\hline & Grad student 4 & & $\$ 0$ \\
\hline \multicolumn{2}{|c|}{ Total stipends } & & $\$ 45,543$ \\
\hline \multicolumn{3}{|c|}{$\begin{array}{l}\text { student fringes } \\
\text { calculated on summer taxable assignment }\end{array}$} & $\$ 1,420$ \\
\hline \multicolumn{3}{|l|}{ Travel } & $\$ 10,000$ \\
\hline \multicolumn{3}{|l|}{ Supplies } & $\$ 8,000$ \\
\hline \multicolumn{3}{|c|}{ Subcontractor } & $\$ 15,000$ \\
\hline \multicolumn{3}{|c|}{ Documentation } & $\$ 0$ \\
\hline \multicolumn{3}{|c|}{ Direct costs } & $\$ 173,848$ \\
\hline \multicolumn{3}{|c|}{ Indirects $(F \& A)$} & $\$ 81,883$ \\
\hline \multicolumn{3}{|c|}{ Equipment } & $\$ 75,200$ \\
\hline Tuition & \multicolumn{2}{|c|}{$\$ 3,2172$ terms $/ 3$ students } & $\$ 19,302$ \\
\hline \multicolumn{3}{|c|}{ Total direct/indirects } & $\$ 350,233$ \\
\hline
\end{tabular}


9.3.3.2 University of Alaska Fairbanks Original Project Budget Year 2 Year Two Budget - S. Patil BP/DOE

\begin{tabular}{|c|c|c|c|}
\hline $\begin{array}{l}\text { Personnel } \\
\text { Senior }\end{array}$ & \multicolumn{2}{|c|}{ \# pay periods } & cost \\
\hline & Patil & 4 & $\$ 10,987$ \\
\hline & Khataniar & 2 & $\$ 5,988$ \\
\hline & Dandekar & 2 & $\$ 5,636$ \\
\hline & Chukwu & 2 & $\$ 7,700$ \\
\hline & & 26 & $\$ 45,178$ \\
\hline Total sala & & & $\$ 75,489$ \\
\hline \multicolumn{2}{|c|}{ Fringe benefits } & & $\$ 22,194$ \\
\hline \multirow[t]{4}{*}{ Others } & Grad student 1 & & $\$ 15,181$ \\
\hline & Grad student 2 & & $\$ 15,181$ \\
\hline & Grad student 3 & & $\$ 15,181$ \\
\hline & Grad student 4 & & $\$ 0$ \\
\hline \multicolumn{2}{|c|}{ Total stipends } & & $\$ 45,543$ \\
\hline \multicolumn{2}{|c|}{ student fringes } & & $\$ 1,420$ \\
\hline \multicolumn{3}{|c|}{ calculated on summer taxable assignment } & \\
\hline \multicolumn{3}{|l|}{ Travel } & $\$ 10,000$ \\
\hline \multicolumn{3}{|l|}{ Supplies } & $\$ 8,000$ \\
\hline \multicolumn{3}{|c|}{ Subcontractor } & $\$ 15,000$ \\
\hline \multicolumn{3}{|c|}{ Documentation } & $\$ 0$ \\
\hline \multicolumn{3}{|c|}{ Direct costs } & $\$ 177,646$ \\
\hline \multicolumn{3}{|c|}{ Indirects (F\&A) } & $\$ 83,671$ \\
\hline \multicolumn{3}{|c|}{ Equipment } & $\$ 0$ \\
\hline \multicolumn{3}{|c|}{$\$ 3,3142$ terms $/ 3$ students } & $\$ 19,884$ \\
\hline \multicolumn{3}{|c|}{ Total direct/indirects } & $\$ 281,201$ \\
\hline
\end{tabular}


9.3.3.3 University of Alaska Fairbanks Original Project Budget Year 3

Year Three Budget - S. Patil BP/DOE

Personnel \# pay periods cost

Senior

Patil
Khataniar
Dandekar
Chukwu
Ogbe
Bandopadhyay
Ganguli
Metz
Post Doc

Total salaries

Post Doc

Fringe benefits

$5 \$ 14,145$

$3 \$ 9,252$

$3 \quad \$ 8,708$

$6 \$ 23,794$

$3 \$ 13,068$

$2 \$ 9,412$

$2 \$ 5,283$

$4 \$ 13,995$

$26 \$ 46,533$

$\$ 144,191$

Others

Grad student 1

Grad student 2

Grad student 3

$\$ 41,815$

Grad student 4

$\$ 15,181$

$\$ 15,181$

$\$ 15,181$

$\$ 0$

Total stipends

$\$ 45,543$

student fringes

$\$ 1,420$

Travel

$\$ 10,000$

Supplies

$\$ 8,000$

Subcontractor

$\$ 15,000$

Documentation

$\$ 0$

Direct costs

$\$ 265,969$

Indirects (F\&A)

$\$ 125,271$

Equipment

$\$ 0$

Tuition

$\$ 3,4132$ terms/3 students

$\$ 20,481$

Total direct/indirects

$\$ 411,720$ 
9.3.3.4 University of Alaska Fairbanks Original Project Budget Year 4 Year Four Budget - S. Patil BP/DOE

\begin{tabular}{|c|c|c|c|}
\hline Personnel & & & \\
\hline & Patil & 5 & $\$ 14,570$ \\
\hline & Khataniar & 3 & $\$ 9,530$ \\
\hline & Dandekar & 3 & $\$ 8,969$ \\
\hline & Ogbe & 3 & $\$ 13,460$ \\
\hline & Bandopadhyay & 2 & $\$ 9,694$ \\
\hline & Ganguli & 2 & $\$ 5,442$ \\
\hline & Post Doc & 26 & $\$ 47,929$ \\
\hline Total salaries & & & $\$ 109,593$ \\
\hline Fringe benefits & & & $\$ 32,549$ \\
\hline Others & Grad student 1 & & $\$ 15,181$ \\
\hline & Grad student 2 & & $\$ 15,181$ \\
\hline & Grad student 3 & & $\$ 15,181$ \\
\hline & Grad student 4 & & $\$ 0$ \\
\hline Total stipends & & & $\$ 45,543$ \\
\hline student fringes & & & $\$ 1,420$ \\
\hline Travel & & & $\$ 10,000$ \\
\hline Supplies & & & $\$ 10,000$ \\
\hline Subcontractor & & & $\$ 15,000$ \\
\hline Documentation & & & $\$ 0$ \\
\hline Direct costs & & & $\$ 224,105$ \\
\hline Indirects (F\&A) & & & $\$ 105,554$ \\
\hline Equipment & & & $\$ 0$ \\
\hline Tuition & $\$ 3,413$ & & $\$ 20,481$ \\
\hline dire & d & & $\$ 350,140$ \\
\hline
\end{tabular}


9.3.3.5 University of Alaska Fairbanks Original Project Budget, Total Project Total Project Budget - S. Patil BP/DOE

\begin{tabular}{|c|c|c|c|c|c|c|}
\hline \multirow{10}{*}{$\begin{array}{l}\text { Personnel } \\
\text { Senior }\end{array}$} & \multicolumn{2}{|c|}{ \# pay periods } & \multicolumn{2}{|c|}{ DOE COST } & \multicolumn{2}{|c|}{ UAF MATCH } \\
\hline & Patil & 18 & $\$$ & 50,368 & $\$$ & 31,409 \\
\hline & Khataniar & 10 & $\$$ & 30,584 & $\$$ & 30,584 \\
\hline & Dandekar & 10 & $\$$ & 28,785 & $\$$ & 19,947 \\
\hline & Chukwu & 10 & $\$$ & 38,970 & $\$$ & 27,073 \\
\hline & Ogbe & 6 & $\$$ & 26,527 & $\$$ & 26,528 \\
\hline & Bandopadhyay & 4 & $\$$ & 19,106 & $\$$ & 19,106 \\
\hline & Ganguli & 4 & $\$$ & 10,725 & $\$$ & 10,725 \\
\hline & Metz & 4 & $\$$ & 13,995 & $\$$ & 13,995 \\
\hline & Post Doc & & $\$$ & 183,502 & & \\
\hline Total salaries & & & $\$$ & 402,564 & $\$$ & 179,366 \\
\hline Fringe benefits & & & $\$$ & 117,153 & $\$$ & 52,237 \\
\hline \multirow[t]{4}{*}{ Others } & Grad student 1 & & $\$$ & 60,724 & $\$$ & \\
\hline & Grad student 2 & & $\$$ & 60,724 & $\$$ & 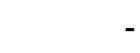 \\
\hline & Grad student 3 & & $\$$ & 60,724 & $\$$ & \\
\hline & Grad student 4 & & $\$$ & & $\$$ & \\
\hline Total stipends & & & $\$$ & 182,172 & $\$$ & \\
\hline student fringes & & & $\$$ & 5,679 & $\$$ & \\
\hline Travel & & & $\$$ & 40,000 & $\$$ & \\
\hline Supplies & & & $\$$ & 34,000 & $\$$ & \\
\hline Subcontractor & & & $\$$ & 60,000 & $\$$ & \\
\hline Documentation & & & $\$$ & - & $\$$ & \\
\hline Direct costs & & & $\$$ & 841,568 & $\$$ & 231,603 \\
\hline Indirects $(\mathrm{F} \& \mathrm{~A})$ & & & $\$$ & 396,379 & $\$$ & 109,085 \\
\hline Equipment & & & $\$$ & 75,200 & $\$$ & \\
\hline Tuition & & & $\$$ & 80,147 & $\$$ & \\
\hline Total direct/ind & rects & & & ,393,294 & $\$$ & 340,688 \\
\hline
\end{tabular}


9.3.3.6 University of Alaska Fairbanks Original Project Budget, UAF Match UAF Match - S. Patil BP/DOE Year $1 \quad$ Year 2

Year 3 Year 4

TOTAL MATCH Personnel \# pay periods cost

Senior

\begin{tabular}{|c|c|c|c|c|c|c|c|}
\hline \multicolumn{2}{|c|}{ Patil } & 3 & $\$ 8,000$ & $\$ 6,180$ & $\$ 8,487$ & $\$ 8,742$ & $\$ 31,409$ \\
\hline & Khataniar & 3 & $\$ 5,814$ & $\$ 5,988$ & $\$ 9,252$ & $\$ 9,530$ & $\$ 30,584$ \\
\hline & Dandekar & 1.5 & $\$ 5,472$ & $\$ 5,636$ & $\$ 4,354$ & $\$ 4,485$ & $\$ 19,947$ \\
\hline & Chukwu & 0 & $\$ 7,476$ & $\$ 7,700$ & $\$ 11,897$ & $\$ 0$ & $\$ 27,073$ \\
\hline & Ogbe & 3 & $\$ 0$ & $\$ 0$ & $\$ 13,068$ & $\$ 13,460$ & $\$ 26,528$ \\
\hline & Bandopadhyay & 2 & $\$ 0$ & $\$ 0$ & $\$ 9,412$ & $\$ 9,694$ & $\$ 19,106$ \\
\hline & Ganguli & 2 & $\$ 0$ & $\$ 0$ & $\$ 5,283$ & $\$ 5,442$ & $\$ 10,725$ \\
\hline & Metz & 0 & $\$ 0$ & $\$ 0$ & $\$ 13,995$ & $\$ 0$ & $\$ 13,995$ \\
\hline \multicolumn{2}{|c|}{ Total salaries } & & $\$ 26,762$ & $\$ 25,504$ & $\$ 75,748$ & $\$ 51,352$ & $\$ 179,366$ \\
\hline \multicolumn{2}{|c|}{ Fringe benefits } & & $\$ 7,520$ & $\$ 7,498$ & $\$ 21,967$ & $\$ 15,251$ & $\$ 52,237$ \\
\hline \multirow[t]{4}{*}{ Others } & Grad student 1 & & $\$ 0$ & $\$ 0$ & $\$ 0$ & $\$ 0$ & $\$ 0$ \\
\hline & Grad student 2 & & $\$ 0$ & $\$ 0$ & $\$ 0$ & $\$ 0$ & $\$ 0$ \\
\hline & Grad student 3 & & $\$ 0$ & $\$ 0$ & $\$ 0$ & $\$ 0$ & $\$ 0$ \\
\hline & Grad student 4 & & $\$ 0$ & $\$ 0$ & $\$ 0$ & $\$ 0$ & $\$ 0$ \\
\hline \multicolumn{2}{|c|}{ Total stipends } & & $\$ 0$ & $\$ 0$ & $\$ 0$ & $\$ 0$ & $\$ 0$ \\
\hline \multicolumn{2}{|c|}{ student fringes } & & $\$ 0$ & $\$ 0$ & $\$ 0$ & $\$ 0$ & $\$ 0$ \\
\hline \multicolumn{2}{|l|}{ Travel } & & $\$ 0$ & $\$ 0$ & $\$ 0$ & $\$ 0$ & $\$ 0$ \\
\hline \multicolumn{2}{|c|}{ Supplies } & & $\$ 0$ & $\$ 0$ & $\$ 0$ & $\$ 0$ & $\$ 0$ \\
\hline \multicolumn{2}{|c|}{ Subcontractor } & & $\$ 0$ & $\$ 0$ & $\$ 0$ & $\$ 0$ & $\$ 0$ \\
\hline \multicolumn{2}{|c|}{ Documentation } & & $\$ 0$ & $\$ 0$ & $\$ 0$ & $\$ 0$ & $\$ 0$ \\
\hline \multicolumn{3}{|c|}{ Direct costs } & $\$ 34,282$ & $\$ 33,002$ & $\$ 97,715$ & $\$ 66,603$ & $\$ 231,603$ \\
\hline \multicolumn{2}{|c|}{ Indirects (F\&A) } & & $\$ 16,147$ & $\$ 15,544$ & $\$ 46,024$ & $\$ 31,370$ & $\$ 109,085$ \\
\hline \multicolumn{2}{|c|}{ Equipment } & & $\$ 0$ & $\$ 0$ & $\$ 0$ & $\$ 0$ & $\$ 0$ \\
\hline \multicolumn{2}{|l|}{ Tuition } & & $\$ 0$ & $\$ 0$ & $\$ 0$ & $\$ 0$ & $\$ 0$ \\
\hline \multicolumn{3}{|c|}{ Total direct/indirects } & $\$ 50,429$ & $\$ 48,546$ & $\$ 143,739$ & $\$ 97,973$ & $\$ 340,688$ \\
\hline
\end{tabular}

